\title{
WHEN TO SUSPECT AN AUTOINFLAMMATORY DISEASE?
}

\author{
KADA POSUMNJATI NA AUTOINFLAMATORNU BOLEST?
}

\author{
Mario Šestan, Marija Jelušić \\ ${ }^{1}$ Division of Clinical Immunology, Rheumatology, and Allergology, Republic of Croatia Ministry of Health \\ Center of Excellence for Pediatric and Adolescent Rheumatology, Department of Pediatrics, \\ University of Zagreb School of Medicine, University Hospital Center Zagreb, Croatia \\ / Zavod za kliničku imunologiju, reumatologiju i alergologiju, Referentni centar za pedijatrijsku i adolescentnu reumatologiju \\ Ministarstva zdravstva Republike Hrvatske, Klinika za pedijatriju, Medicinski fakultet Sveučilišta u Zagrebu, \\ Klinički bolnički centar Zagreb, Zagreb, Hrvatska
}

Corresponding author / Adresa autora za dopisivanje:

Prof. dr. sc. Marija Jelušić, dr. med.

Division of Clinical Immunology, Rheumatology and Allergology

/ Zavod za kliničku imunologiju, reumatologiju i alergologiju

Republic of Croatia Ministry of Health Center of Excellence for Pediatric and Adolescent Rheumatology

/ Referentni centar za pedijatrijsku i adolescentnu reumatologiju Ministarstva zdravstva Republike Hrvatske

Department of Pediatrics / Klinika za pedijatriju

University of Zagreb School of Medicine / Medicinski fakultet Sveučilišta u Zagrebu

University Hospital Center Zagreb / Klinički bolnički centar Zagreb

Kišpatićeva 12, 10000 Zagreb

e-pošta: marija.jelusic@mef.hr

Received / Primljeno: February 17, 2020 / 17. veljače 2020.

Accepted / Prihvaćeno: May 22, 2020 / 22. svibnja 2020.

\section{Abstract}

Autoinflammatory diseases are clinical disorders caused by a deficiency or dysregulation of innate immunity, characterized by recurrent or persistent inflammation (increased levels of acute phase reactants) and the absence of a primary pathogenic role of adaptive immunity (autoreactive $\mathrm{T}$ lymphocytes or antibody production). They are clinically manifested by recurrent episodes of systemic inflammation due to the activation of an intense nonspecific inflammatory reaction with no apparent or sufficient cause.

In terms of pathogenesis, autoinflammatory diseases can be divided into monogenic, or those that are caused by a mutation in a well-defined gene, and non-monogenic, also referred to as unclassified. According to the three main pathogenic patterns of emergence in monogenic autoinflammatory diseases described to date, they are divided into inflammasomopathies, interferonopathies, and ubiquitinopathies. Clinically, inflammasomopathies are most commonly manifested by fever (often periodic type), rash, serositis, hepatosplenomegaly, and lymphadenopathy. The therapeutic approach in many of these diseases is based on the use of an interleukin-1 inhibitor. Interferonopathies are most commonly manifested as acral and lung vasculopathy and fibrosis, with an onset of skin changes like chilblains, intracranial calcifications, and myositis. Janus kinase inhibitors are used in the treatment. Ubiquitinopathies are most commonly manifested by granuloma, ulceration, uveitis, and immunodeficiency. The therapeutic approach in these diseases is based on the use of tumor necrosis factor-alpha inhibitors.

Unclassified autoinflammatory diseases include diseases that meet the clinical and biological criteria for autoinflammatory diseases but to date have no detected genetic background (for example, syndrome of periodic fever, aphthous stomatitis, pharyngitis and cervical adenitis, Schnitzler syndrome, or systemic-onset juvenile idiopathic arthritis), and some multifactorial diseases that are polygenic or caused by complex interactions of multiple genes and environmental factors and not associated with Mendelian inheritance patterns (eg., gout, Behcet disease).

In the diagnosis of patients with suspected autoinflammatory disease, it is necessary to exclude infections, malignancies, immunodeficiencies, and rheumatic diseases. The main indication for genetic testing is the presence of clinical symptoms that meet the criteria for one or more autoinflammatory diseases. There are a number of unanswered questions in genetic diagnostics, the main problem being the interpretation of the results.

KEYwORDs: Hereditary autoinflammatory diseases - classification, diagnosis, genetics, therapy; Autoimmune diseases - diagnosis, immunology, therapy; Inflammation - immunology; Fever - genetics, immunology; Immunity, 
innate - immunology; Inflammasomes - immunology; Interferon type I - immunology; Ubiquitins - immunology; Interleukin-1 - antagonists and inhibitors; Janus kinase inhibitors - therapeutic use; Tumor necrosis factor-alpha antagonists and inhibitors

\section{SAŽETAK}

Autoinflamatorne bolesti klinički su poremećaji uzrokovani nedostatkom ili poremećajem regulacije prirođene imunosti, a obilježavaju ih ponavljana ili stalna upala (povišeni reaktanti akutne faze) i odsutnost primarne patogenetske uloge stečene imunosti (autoreaktivni T-limfociti ili proizvodnja protutijela). Klinički se manifestiraju ponavljanim epizodama sustavne upale zbog aktivacije intenzivne nespecifične upalne reakcije bez očitog ili dovoljnog uzroka.

$\mathrm{U}$ patogenetskom smislu mogu se podijeliti na monogenske, odnosno na one koje su uzrokovane mutacijom u jednom, dobro definiranom genu i na one koje nisu monogenske, a označavaju se i kao neklasificirane. Prema tri glavna patogenetska obrasca nastanka, do danas opisane monogenske autoinflamatorne bolesti dijele se na inflamasomopatije, interferonopatije i ubikvitinopatije. Klinički se inflamasomopatije najčešće manifestiraju vrućicom (nerijetko periodična tipa), osipima, serozitisom, hepatosplenomegalijom i limfadenopatijom. Terapijski pristup u velikom broju ovih bolesti temelji se na primjeni inhibitora interleukina 1 . Interferonopatije se najčešće manifestiraju vaskulopatijama ekstremiteta i pluća, nastankom fibroznih promjena, kožnih promjena nalik na ozebline, intrakranijalnim kalcifikacijama i miozitisom. U liječenju se rabe inhibitori Janusove kinaze. Ubikvitinopatije se najčešće očituju nastankom granuloma, ulceracija, uveitisa te imunodeficijencijom. Terapijski pristup u ovim bolestima temelji se na primjeni inhibitora čimbenika tumorske nekroze alfa.

U skupinu neklasificiranih autoinflamatornih bolesti ubrajaju se bolesti koje zadovoljavaju kliničko-biološke kriterije za autoinflamatorne bolesti, ali do danas nemaju otkrivenu gensku podlogu (primjerice, sindrom periodične vrućice, aftoznog stomatitisa, faringitisa i adenitisa, Schnitzlerin sindrom, sustavni oblik juvenilnog idiopatskog artritisa), kao i neke multifaktorske bolesti koje su poligenske, odnosno uvjetovane složenim interakcijama većeg broja gena i okolišnih čimbenika te nisu povezane s mendelovskim obrascem nasljeđivanja (primjerice, giht, Behçetova bolest).

Pri obradi bolesnika sa sumnjom na autoinflamatornu bolest potrebno je isključiti infekcije, zloćudne bolesti, imunodeficijencije i reumatske bolesti. Glavna je indikacija za gensko testiranje prisutnost kliničkih simptoma koji ispunjavaju kriterije za jednu ili više autoinflamatornih bolesti. U genskoj dijagnostici postoji niz neodgovorenih pitanja, među kojima je glavni problem interpretacija nalaza.

KljuČNe RijeČI: Autoinflamatorne bolesti - dijagnoza, genetika, klasifikacija, liječenje; Autoimunosne bolesti dijagnoza, imunologija, liječenje; Upala - imunologija; Vrućica - genetika, imunologija; Prirođena imunost - imunologija; Inflamasomi - imunologija; Interferon tip I - imunologija; Ubikvitini - imunologija; Interleukin-1 - antagonisti i inhibitori; Inhibitori janusove kinaze - terapijska uporaba; Čimbenik tumorske nekroze alfa - antagonisti i inhibitori

\section{DEFINITION \\ OF AUTOINFLAMMATORY DISEASES}

Autoinflammatory or self-inflammatory diseases are a relatively new category in the group of immunity disorders, and they differ from autoimmune diseases. They were defined as a specific clinical entity group in 1999 owing to the discovery of the genes involved in the pathogenesis of familial Mediterranean fever (FMF) syndrome and Tumor Necrosis Factor Receptor-Associated Periodic Syndrome (TRAPS) (1). In the same year, Daniel Kastner's research team defined autoinflammatory diseases as a group of clinical syndromes characterized by an inflammatory process of no known cause without detectable autoantibodies (i.e., antibodies directed against self-antigens) or antigen-specific T-lymphocytes / autoreactive T-lymphocyte clones (2). However, as knowledge on the etiopathogenesis of autoinflammatory disease grew, and it

\section{DEFINICIJA AUTOINFLAMATORNIH BOLESTI}

Autoinflamatorne ili samoupalne bolesti relativno su nova skupina bolesti izdvojena iz skupine autoimunosnih bolesti. Prvi su put definirane kao zasebna skupina bolesti 1999. godine zahvaljujući otkriću gena koji su u podlozi dvaju sindroma: obiteljske mediteranske vrućice i periodične vrućice vezane uz receptor čimbenika tumorske nekroze (1). Grupa istraživača predvođena Danielom Kastnerom 1999. godine definirala je autoinflamatorne bolesti kao sindrome koje obilježava naizgled ni s čim izazvana upala bez prisutnosti znatnog titra autoprotutijela, odnosno protutijela usmjerenih na vlastite antigene ili T-limfocita specifičnih za antigen, odnosno autoreaktivnih klonova T-limfocita (2). Ipak, s rastućim brojem spoznaja o etiopatogenezi autoinflamatornih bolesti pokazala se potreba za promjenom ove prvotne definicije, budući da je postalo 
was realized that there are exacerbating factors such as immunization in mevalonate kinase deficiency and enviromental cold in cryopirin-associated periodic syndrome, it became necessary to change the original definition. Therefore, in 2010 Kastner and his associates defined autoinflammatory diseases as disorders characterized by a hyperinflammatory condition mediated by innate immunity mechanisms in a predisposed host (3). The new definition is broad enough to encompass both monogenic periodic fever syndromes inherited in a Mendelian fashion and complex polygenic inheritance disorders, because, as we know today, autoinflammatory disorders are not only typical monogenic autoinflammatory inheritance disorders formerly known as inherited periodic fever syndromes, but also various polygenic autoinflammatory diseases such as inflammatory bowel disease, gout, autoantibody-negative vasculitis, idiopathic uveitis, etc. (4). Interestingly, several rather prevalent conditions such as type 2 diabetes mellitus and atherosclerosis also have an autoinflammatory component. This latest definition makes it easier to discriminate between innate immunity-associated autoinflammatory diseases and adaptive immunity-associated autoimmune diseases; it also implies that these conditions are a result of an innate immunity system disorder. Hopefully, this knowledge will increase clinical awareness of these rare and often unrecognized disorders, making them easier to diagnose and aiding patients in getting efficient treatment. Since in the past there were no treatment options for these rare conditions, diagnosing them was practically an academic effort. Today, this has changed with novel therapies and growing knowledge.

In the light of new medical knowledge, one can summarize that autoinflammatory diseases are clinical disorders characterized by recurrent or persistent inflammation (increased acute phase reactants) and a deficient primary pathogenic role of adaptive immunity (autoreactive T-lymphocytes or autoantibodies), resulting from a lack of regulation or dysregulation of innate immunity (5). Those diseases manifest with recurrent episodes of systemic inflammation due to intense non-specific inflammatory activation without a known or sufficient cause. Pathogenically speaking, the innate immune system is non-specifically or inadequately activated. Disease flares can occur due to trauma, immunization, infection, stress, etc., or without any apparent triggers.

The key differences between autoinflammatory and autoimmune diseases are shown in Table 1. Although it may seem that these differences are relatively obvious, in clinical practice the features of autoinflammatory and autoimmune disease tend to overlap. Thus, there is a tendency to abandon the classical division into autoinflammatory and autoimmune disorders in favor of bjelodano kako postoje čimbenici koji mogu potaknuti upalne epizode ovih bolesti poput cijepljenja vezano uz manjak mevalonat kinaze ili hladnoće uz kriopirinske sindrome periodične vrućice. Stoga su 2010. godine Kastner i suradnici predložili novu definiciju autoinflamatornih bolesti kao poremećaja koje obilježava prekomjerno pojačana upala posredovana stanicama i molekulama prirođenog imunosnog sustava, pri čemu postoji znatna predispozicija domaćina (3). Ova je definicija dovoljno široka da obuhvati sindrome periodičnih vrućica $s$ mendelovskim obrascem nasljeđivanja, odnosno monogenske poremećaje, ali i složene poligenske i nasljedne poremećaje. Naime, prema suvremenim spoznajama, autoinflamatornim bolestima ne pripadaju samo klasični monogenski nasljedni autoinflamatorni poremećaji, prije poznati kao nasljedni sindromi periodičnih vrućica, nego i različite poligenske autoinflamatorne bolesti poput upalnih bolesti crijeva, gihta, vaskulitisa koji nisu povezani s protutijelima, idiopatskih uveitisa itd. (4). Ovdje valja pridometnuti da i neke raširene bolesti poput šećerne bolesti tipa 2 i ateroskleroze imaju komponente autoinflamacije. Definicija koju su donijeli Kastner i suradnici, s jedne strane, omogućuje razlikovanje autoinflamatornih bolesti vezanih uz sustav prirođene imunosti od autoimunosnih bolesti koje su vezane uz sustav stečene imunosti. S druge strane, definicija implicira postojanje poremećaja na razini prirođene imunosti u podlozi bolesti. To je važno jer se time povećava vjerojatnost da će s porastom svijesti o postojanju autoinflamatornih bolesti koje su rijetke u kliničkoj praksi kompleksni bolesnici koji su godinama ostali neprepoznati napokon dobiti konačnu dijagnozu, ali i učinkovitu terapiju. Naime, prije su ove bolesti bile relativno nezanimljive budući da se o njima malo znalo i nije postojalo djelotvorno liječenje pa točna dijagnoza nije bila klinički izazov. No, otkad su se naše spoznaje proširile, a učinkovita terapija postala dostupnom, ispravna dijagnoza dobila je novo značenje.

Možemo, dakle, reći da su autoinflamatorne bolesti klinički poremećaji uzrokovani nedostatkom ili poremećajem regulacije prirođene imunosti, a obilježavaju ih ponavljana ili stalna upala (povišeni reaktanti akutne faze) i odsutnost primarne patogenetske uloge stečene imunosti (autoreaktivni T-limfociti ili proizvodnja protutijela) (5). Klinički se manifestiraju ponavljanim epizodama sustavne upale zbog aktivacije intenzivne nespecifične upalne reakcije bez očitog ili dovoljnog uzroka. U patogenetskom smislu riječ je o imunosno nespecifičnoj aktivaciji sustava prirođene imunosti, odnosno o neprimjerenoj aktivaciji prirođenog imunosnog sustava. Napadaji ne moraju imati očite okidače, ali mogu biti i nakon traume, cijepljenja, infekcije, stresa... 
TABLE 1. Differences between autoinflammatory and autoimmune diseases (modified according to reference No. 6) TABLICA 1. Razlike izmedu autoinflamatornih i autoimunosnih bolesti (prilagođeno prema referenciji 6.)

\begin{tabular}{|l|l|l|}
\hline $\begin{array}{l}\text { Characteristics } \\
\text { / Karakteristika }\end{array}$ & $\begin{array}{l}\text { Autoinflammatory disease } \\
\text { / Autoinflamatorna bolest }\end{array}$ & $\begin{array}{l}\text { Autoimmune disease } \\
\text { / Autoimunosna bolest }\end{array}$ \\
\hline $\begin{array}{l}\text { Immune system disorder } \\
\text { / Imunosni poremećaj }\end{array}$ & Native immunity / prirođena imunost & Acquired immunity / stečena imunost \\
\hline $\begin{array}{l}\text { Key cells } \\
\text { / Ključne stanice u patogenezi }\end{array}$ & $\begin{array}{l}\text { Neutrophils, macrophages } \\
\text { / neutrofili, makrofagi }\end{array}$ & $\begin{array}{l}\text { B and T-lymphocytes } \\
\text { / B-limfociti i T-limfociti }\end{array}$ \\
\hline Antibodies / Protutijela & Few or none / malo ili nimalo autoprotutijela & Positive / autoprotutijela prisutna \\
\hline $\begin{array}{l}\text { Clinical characteristics } \\
\text { / Klinička obilježja }\end{array}$ & $\begin{array}{l}\text { Recurrent episodes, often unprovoked / ponavljane } \\
\text { epizode, često naizgled bez provocirajućeg čimbenika }\end{array}$ & $\begin{array}{l}\text { Persistent progression } \\
\text { / kontinuirana progresija }\end{array}$ \\
\hline $\begin{array}{l}\text { Pathogenetic concept } \\
\text { / Patogenetski koncept }\end{array}$ & $\begin{array}{l}\text { Tissue-specific danger signals } \\
\text { / signali opasnosti specif̌čni za tkiva }\end{array}$ & $\begin{array}{l}\text { Autoantigen intolerance } \\
\text { / poremećaj tolerancije na vlastite antigene }\end{array}$ \\
\hline $\begin{array}{l}\text { Genetic basis } \\
\text { / Genska osnova }\end{array}$ & $\begin{array}{l}\text { Cytokines and microbe-recognition pathways } \\
\text { / citokini i putovi za prepoznavanje mikroorganizama }\end{array}$ & $\begin{array}{l}\text { Association with MHC II system } \\
\text { and acquired immunity genes } \\
\text { / udruženost s MHC-om II i genima } \\
\text { odgovornima za stečenu imunost }\end{array}$ \\
\hline $\begin{array}{l}\text { Investigations } \\
\text { / Laboratorijska dijagnostika }\end{array}$ & $\begin{array}{l}\text { Gene sequencing } \\
\text { / sekvenciranje gena odgovornih za nastanak bolesti }\end{array}$ & $\begin{array}{l}\text { Autoantibody and MHC II gene testing } \\
\text { / dokaz autoprotutijela i gena MHC-a }\end{array}$ \\
\hline Treatment / Liječenje & $\begin{array}{l}\text { Inhibition of native immunity cytokine cascade } \\
\text { (anti-TNF, anti-IL-1, anti-IL.6) } \\
\text { Inhibition of neutrophil function (inflammasomes), } \\
\text { i.e., with colchicine } \\
\text { / blokada citokinske kaskade uključene u prirođenu } \\
\text { imunost (npr., anti-TNF, anti-IL-1, anti-IL-6); } \\
\text { blokada funkcije neutrofila (inflamasoma) (npr., } \\
\text { kolhicin) }\end{array}$ & $\begin{array}{l}\text { T-cell blockade (i.e., mycophenolate-mofetil, } \\
\text { cyclosporin) } \\
\text { B-cell blockade (i.e., rituximab) } \\
\text { / blokada T-stanica } \\
\text { (npr., mikofenolat-mofetil, ciklosporin); } \\
\text { blokada B-limfocita (npr., rituksimab) }\end{array}$ \\
\hline
\end{tabular}

Legend / Legenda:

MHC: major histocompatibility complex / geni glavnoga sustava tkivne snošljivosti; TNF: tumor necrotizing factor / čimbenik tumorske nekroze; IL-1: interleukin 1; IL-6: interleukin 6

defining these conditions as immune regulation disorders divided into several categories according to the degree of overlap of innate and adaptive immunity disorders. Immune regulation disorders encompass not only autoimmune and autoinflammatory disease, but also primary immunodeficiency syndromes and several hematologic disorders such as hemophagocytic lymphohistiocytosis, autoimmune lymphoproliferative syndrome, etc. $(6,7)$.

Since the definition of autoinflammatory diseases is relatively new, incidence data is somewhat sparse. In a paper published in 2013 by Hemminki et al., the presumed incidence of these disorders in Sweden was 2.83 per $1,000,000$. However, since autoinflammatory conditions often go unrecognized by clinicians, it is believed that the real numbers are higher, thus making it necessary to increase awareness of these diseases. The prevalence is variable, from 1:1,000 in Sweet syndrome to $1: 1,000,000$ in PFAPA syndrome (periodic fever, aphthous stomatitis, pharyngitis, adenitis) (9).

\section{OVERVIEW OF THE PATHOGENESIS OF AUTOINFLAMMATORY DISEASES}

Since new autoinflammation-associated genes are constantly being discovered, and new light is being
Ključne razlike između autoinflamatornih i autoimunosnih bolesti prikazane su na tablici 1 . Iako se čini da je distinkcija između autoimunosnih i autoinflamatornih bolesti jasna, u praksi se kod većine poremećaja u različitom stupnju preklapaju fenotipske značajke autoimunosti i autoinflamacije. Stoga se sve više napušta dihotomna podjela autoimunosno/autoinflamatorno te se u svjetlu novih spoznaja govori o poremećajima imunosne regulacije koji obuhvaćaju nekoliko kategorija u kojima se u različitoj mjeri preklapaju poremećaji prirođene i stečene imunosti. U poremećaje imunosne regulacije uključuju se, osim autoimunosnih i autoinflamatornih bolesti, i primarne imunodeficijencije, ali i neki hematološki poremećaji (hemofagocitna limfohistiocitoza, autoimunosni limfoproliferativni sindrom itd.) $(6,7)$.

Budući da su autoinflamatorne bolesti relativno novodefinirana skupina bolesti, podatci o njihovoj učestalosti slabo su poznati. Hemminki i suradnici u radu iz 2013. godine procijenili su da incidencija autoinflamatornih bolesti u Švedskoj iznosi 2,83 bolesnika na milijun stanovnika (8), no budući da se radi o bolestima koje su relativno nepoznate liječnicima koji se njima uže ne bave i da imaju malenu incidenciju, vjeruje se da znatan broj bolesnika ostaje neprepoznat te 
TABLE 2. Summary of pathogenesis of the most common autoinflammatory diseases

TABLICA 2. Sumarni prikaz patogeneze najčešćih autoinflamatornih bolesti

\begin{tabular}{|l|l|l|l|}
\hline & $\begin{array}{l}\text { Inflammasomopathies } \\
\text { / Inflamasomopatije }\end{array}$ & $\begin{array}{l}\text { Interferenopathies } \\
\text { / Interferonopatije }\end{array}$ & $\begin{array}{l}\text { Ubiquitinopathies } \\
\text { (NF-KBpathies/TNFapathies) } \\
\text { / Ubikvitinopatije } \\
\text { (NF-kBpatije/TNF-apatije) }\end{array}$ \\
\hline $\begin{array}{l}\text { Pathogenesis } \\
\text { / Patogenetski } \\
\text { mehanizam }\end{array}$ & $\begin{array}{l}\text { Inflammasome overactivation } \\
\text { / prekomjerna aktivacija inflamasoma }\end{array}$ & $\begin{array}{l}\text { Interferon type 1 overactivation } \\
\text { / prekomjerna aktivacija interferona } \\
\text { tipa I }\end{array}$ & $\begin{array}{l}\text { Disordered ubiquitination } \\
\text { / poremećena ubikvitinacija }\end{array}$ \\
\hline $\begin{array}{l}\text { Genetic basis } \\
\text { / Genska osnova }\end{array}$ & $\begin{array}{l}\text { Functional and somatic mutations } \\
\text { / mutacije dobitka funkcije i somatske } \\
\text { mutacije }\end{array}$ & $\begin{array}{l}\text { Variable; various genes } \\
\text { / varijabilna, različiti geni }\end{array}$ & $\begin{array}{l}\text { Function loss mutations, } \\
\text { haploinsufficiency } \\
\text { / mutacije gubitka funkcije, } \\
\text { haploinsuficijencija }\end{array}$ \\
\hline $\begin{array}{l}\text { Clinical findings } \\
\text { / Klinička obilježja }\end{array}$ & $\begin{array}{l}\text { Episodic fever, rash } \\
\text { / epizode vrućice, osipi }\end{array}$ & $\begin{array}{l}\text { Lung and extremitiy vasculopathy; } \\
\text { fibrosis; CNS calcifications } \\
\text { / vaskulopatija okrajina i pluća; } \\
\text { fibroza; kalcifikacije u središnjem } \\
\text { živčanom sustavu }\end{array}$ & $\begin{array}{l}\text { Granuloma, uveitis, ulcerations; } \\
\text { overlap with immunodeficiencies } \\
\text { / granulomi, uveitis, ulceracije; } \\
\text { preklapanje s imunodeficijencijama }\end{array}$ \\
\hline $\begin{array}{l}\text { Treatment } \\
\text { / Lijekovi }\end{array}$ & $\begin{array}{l}\text { IL-1 inhibitors } \\
\text { / inhibitori IL-1 }\end{array}$ & $\begin{array}{l}\text { JAK inhibitors } \\
\text { / inhibitori JAK-a }\end{array}$ & $\begin{array}{l}\text { TNFa inhibitors } \\
\text { / inhibitori TNF- } \alpha\end{array}$ \\
\hline
\end{tabular}

Legend / Legenda:

IL-1: interleukin 1; JAK: Janus kinase / Janusove kinaze; TNF- $\alpha$ : tumor necrotizing factor alfa / čimbenik tumorske nekroze alfa;

CNS: central nervous system

shed on the mechanisms occurring in these disorders, explaining the pathogenesis of autoinflammation is not a simple task. Autoinflammatory diseases can be divided into monogenic (i.e., resulting from a mutation in one well-defined gene) and non-monogenic or unclassified (10). Conditions falling into the latter group are those with clinical and biological features of autoinflammatory diseases and no known causative gene or genes (for example, PFAPA syndrome, Schnitzler syndrome, systemic juvenile idiopathic arthritis) as well as some multifactorial disorders which are polygenic, i.e., defined by complex interactions of multiple genetic and environmental factors, showing no features of Mendelian inheritance pattern (e.g., gout, Behçet disease).

The majority of known monogenic autoinflammatory diseases are in fact inflammasomopathies since they result from mutations in inflammasome component genes. However, one must be aware that this is not the only autoinflammatory pathogenic mechanism (Table 2). There are several pathogenic patterns which define the known monogenic autoinflammatory diseases as inflammasomopathies, interferonopathies, ubiquitinopathies, complementopathies, and others. (10).

Inflammasomopathies result from mutations of genes associated with components of inflammasomes, intracellular multiprotein complexes that form in granulocyte and macrophage cytoplasm as a response to so-called danger signals. Danger signals are in fact various extracellular molecules derived from microorganisms or damaged cells (11). By binding to respective receptors they trigger an inflammatory cascade je potrebno povećati svijest o postojanju tih bolesti. Prevalencija može varirati u rasponu od $1: 1000$ ljudi kao pri Sweetovu sindromu do $1: 1.000 .000$, što je slučaj sa sindromom PFAPA (engl. Periodic fever, aphthous stomatitis, pharyngitis, adenitis) (9).

\section{PREGLED PATOGENEZE AUTOINFLAMATORNIH BOLESTI}

$S$ obzirom na to da se kontinuirano otkrivaju novi geni povezani s autoinflamatornim bolestima te dolazi do novih spoznaja o mehanizmima uključenima u njihov nastanak, nije nimalo jednostavan zadatak objasniti njihovu patogenezu. Ugrubo se autoinflamatorne bolesti mogu podijeliti na monogenske, dakle, one koje su uzrokovane mutacijom u jednom, dobro definiranom genu, i na one koje nisu monogenske, a označavaju se i kao neklasificirane (10). U tu skupinu ubrajaju se bolesti koje zadovoljavaju kliničko-biološke kriterije za autoinflamatorne bolesti, ali do danas nemaju otkrivenu gensku podlogu (primjerice, sindrom PFAPA, Schnitzlerin sindrom, sustavni oblik juvenilnog idiopatskog artritisa), kao i neke multifaktorske bolesti koje su poligenske, odnosno uvjetovane složenim interakcijama većeg broja gena i okolišnih čimbenika te nisu povezane s mendelovskim obrascem nasljeđivanja (primjerice, giht, Behçetova bolest).

Glavnina do danas identificiranih monogenskih autoinflamatornih bolesti rezultat je mutacija u genima za komponente inflamasoma pa se ubrajaju u skupinu inflamasomopatija. Odmah treba naglasiti da to nije i jedini patogenetski mehanizam nastanka autoinflamatornih bolesti (tablica 2.). Može se reći da postoji nekoliko patogenetskih obrazaca nastanka do danas opisa- 
consisting of two steps: the first step, "signal 1", mediated by nuclear factor kappa B (NF-kB), and the second step, "signal 2", which leads to inflammasome formation. "Signal 1" triggers the transcription of inflammasome components, pro-interleukin 18 and pro-interleukin 1 beta (pro-IL-1B), a precursor of interleukin 1B (IL-1B). "Signal 2", as mentioned, results in inflammasome formation leading to caspase- 1 activation that transforms pro-IL-1B into IL-1B and pro-IL-18 into IL-18. Interleukins $1 \mathrm{~B}$ and 18 are active forms which leave the cell and incite inflammation $(9,12)$.

Various genes for various inflammasomes are mutated in various inflammasomapathies (10): NLRP1 (arthritis and dyskeratosis syndrome), NRLP3 (cryopirine-associated periodic fever syndromes), NRLC4 (macrophage activation syndrome, syndrome of enterocolitis and self-inflammation), NLRP12 (FCAS2, i.e., familial cold inflammatory syndrome 2). The mentioned mutations lead to an overproduction of proinflammatory cytokines, primarily IL-1 but also IL6 , IL-18, and TNF- $\alpha$ (tumor necrosis factor $\alpha$ ). Familial Mediterranean fever and pyrin-associated autoinflammatory disease with neutrophilic dermatosis are a consequence of the pyrin gene mutation. Mevalonate kinase defficiency (formerly known as hyper-IgD syndrome) also results from an overstimulation of pyrin and overproduction of IL-1. Mutations of the TNFRSF1A gene also lead to inflammasome overactivation. PAPA syndrome (pyogenic sterile arthritis, pyoderma gangrenosum, acne) is associated with mutations of the PSTPIP1 gene responsible for encoding an adaptor protein that binds to pyrin; due to this mutation IL-1 is overproduced. Under normal conditions, the activity of proinflammatory cytokines IL-1 and IL-36 is controlled by endogenous antagonists IL1RN and IL36RN. Their mutations result in a dysregulation of cytokine signaling and amplification of the inflammatory response. Gene mutations of IL1RN are responsible for DIRA syndrome (deficiency of IL-1 receptor antagonist), and IL36N gene mutations result in DITRA syndrome (deficiency of interleukin thirty-six receptor antagonist). Most common clinical findings in inflammasomopathies are fever (mostly periodic), rash, serositis, hepatosplenomegaly, and lymphadenopathy. The basis of management in the majority of these disorders are IL- 1 inhibitors.

Interferonopathies are a group of disorders resulting from an overactivation of interferon type 1 (IFN- $\alpha$, IFN- $\beta)(13,14)$. Interferons can activate Janus kinases (JAK) and signal transducers and activators of transcription (STAT) proteins, leading to the transcription of multiple genes associated with the production of cytokines, chemokines, and apoptosis-controlling proteins, as well as to the liberation of proinflammatory cytokines from innate immunity cells. Inteferonopa- nih monogenskih autoinflamatornih bolesti, a to su inflamasomopatije, interferonopatije, ubikvitinopatije, komplementopatije i ostale (10).

Inflamasomopatije nastaju zbog mutacija gena vezanih uz komponente inflamasoma, a to su unutarstanični multiproteinski kompleksi koji se okupljaju u citoplazmi granulocita i makrofaga pod utjecajem signala opasnosti. Riječ je o različitim molekulama u izvanstaničnoj tekućini koje potječu iz različitih mikroorganizama odnosno molekulama što potječu od oštećenja vlastitih stanica (11). Nakon njihova vezanja za odgovarajuće receptore otpočinje upalna kaskada koja se sastoji od dva koraka što se označuju kao: signal 1 , koji je posredovan nuklearnim čimbenikom kapa B (NF-kB), i signal 2 što završava stvaranjem inflamasoma. Signal 1 rezultira poticanjem transkripcije za komponente inflamasoma i za prointerleukin $1 \beta$ (pro-IL-1 $\beta$ ), koji je prekursor interleukina $1 \beta$ (IL-1 $\beta$ ), te prointerleukin 18 . Signal 2 rezultira formiranjem inflamasoma čime se omogućuje aktivacija kaspaze 1 koja cijepa pro-IL-1 $\beta$ u IL-1 $\beta$ odnosno pro-IL-18 u IL-18 koji su aktivne forme, izlaze iz stanice i potiču upalu $(9,12)$.

$\mathrm{U}$ inflamasomopatijama dolazi do mutacija gena za različite inflamasome (10): NLRP1 (sindrom s artritisom i diskeratozom), NLRP3 (kriopirinski sindromi periodične vrućice), NLRC4 (sindrom aktivacije makrofaga i sindrom enterokolitisa i samoupale), NLRP12 (sindrom periodične vrućice FCAS2 prema engl. $\mathrm{Fa}$ milial cold autoinflammatory syndrome 2). Zbog tih mutacija dolazi do prekomjernog stvaranja proupalnih citokina, ponajprije IL-1, ali i IL-6, IL-18 te TNF- $\alpha$ (čimbenik tumorske nekroze alfa). Mutacijom gena za pirin, a to je protein koji je dio kompleksa inflamasoma, dolazi do nastanka obiteljske mediteranske vrućice i autoinflamatorne bolesti povezane s pirinom uz neutrofilnu dermatozu. Zbog manjka mevalonat kinaze (nekoć poznat pod nazivom sindrom hiper-IgD) također dolazi do prekomjerne stimulacije pirina i prekomjerne produkcije IL-1. Kod mutacije u genu TNFRSF1A dolazi do prekomjerne aktivacije inflamasoma. U inflasomopatije ubraja se i sindrom PAPA (piogeni sterilni artritis, gangrenozna pioderma, akne) povezan s mutacijom u genu PSTPIP1 koji kodira adaptorski protein što se može vezati za pirin, pri čemu ponovo dolazi do prekomjerne produkcije IL-1. Aktivnost proupalnih citokina IL-1 i IL-36 u normalnim uvjetima ograničavaju endogeni antagonisti kao što su IL-1RN i IL-36RN. Zbog njihovih mutacija dolazi do poremećaja regulacije citokinske signalizacije i pojačanja upalnog odgovora. Tako zbog mutacije gena IL1RN nastaje sindrom DIRA (engl. Deficiency of IL-1-receptor antagonist), a mutacijom gena IL36RN sindrom DITRA (engl. Deficiency of interleukin thirty-six-receptor antagonist). Klinički se inflamasomopatije najčešće manifestiraju vrućicom (nerijetko periodičnog tipa), 
thies manifest as extremity and lung vasculopathies, fibrosis, cold-sore-like skin changes, intracranial calcium deposits, and myositis. Examples of interferonopathies are: Aicardi-Goutieres syndrome resulting from DNA repairing TREX1 gene mutations that lead to a hyperproduction of IFN- $\alpha$ type I; STING-associated vasculopathy with onset in infancy (SAVI), a severe vasculitis resulting from STING (stimulator of interferon genes) gene mutations; and chronic atypical neutrophilic dermatosis with lypodystrophy and elevated temperature (CANDLE). JAK inhibitors are the foundation of treatment.

Ubiquitinopathies or NF-kBpathies affect one or more molecules called ubiqutins. These are proteins that mark other proteins for catabolism by binding to them. They are also of importance for the stability, function, and intracelullar position of various proteins. The aforementioned binding process is named ubiqutinization, whose opposite is deubiqutinization. LUBAC (linear ubiquitin chain assembly complex) is a protein complex built from several ubiquitin proteins (HOP, HOIL-1, SHARPIN), and its role is to activate the NF$\mathrm{kB}$ signaling pathway. Mutations in the LUBAC gene result in autoinflammation, immunodeficiency, and myopathy. A20 and OTULIN molecules are deubiquitinases that inhibit the NF-kB signaling pathway; if their respective genes are mutated, autoinflammatory disorders occur: haploinsufficiency A20 and otulipenia $(15,16)$. Since ubiquitinopathies are associated with NF-kB signaling pathway abnormalities, they are often called NF-kBpathies. Common clinical features are granulomas, ulcerations, uveitis, and immunodeficiency. The basis of treatment are TNF- $\alpha$ inhibitors, thus these disorders are also known as TNF- $\alpha$-pathies.

Complementopathies result from inappropriate complement activation and some of the disorders in this group are autoinflammatory diseases in nature (17). An example is aHUS, atypical hemolytic-uremic syndrome, caused by mutations in the CFH, THBD, CFI, and CD46 genes, which leads to anemia, thrombocytopenia, and renal failure.

\section{OVERVIEW OF THE MOST COMMON AUTOINFLAMMATORY DISORDERS ACCORDING TO PATHOGENESIS}

\section{Inflammasomopathies}

Members of this group of disorders are monogenic periodic fever syndromes (i.e., familial Mediterranean fever, mevalonate kinase deficiency, TNF-receptor-associated periodic fever, cyropirine-associated periodic fever syndromes), which were in fact the first described examples of autoinflammatory diseases; DIRA syndrome, Majeed syndrome, as well as a subgroup known as resistent inflammasomopathies which includes osipima, serozitisom, hepatosplenomegalijom i limfadenopatijom. Terapijski pristup u velikom broju ovih bolesti temelji se na primjeni inhibitora IL-1.

Interferonopatije čine grupu poremećaja s prekomjernom aktivacijom interferona tipa I (IFN- $\alpha$, IFN- $\beta$ ) $(13,14)$. Interferoni mogu aktivirati Janusove kinaze (JAK) i proteine koji posreduju u aktivaciji i prijenosu signala (engl. Signal transducers and activators of the transcription - STAT). Na kraju dolazi do transkripcije brojnih gena uz stvaranje citokina, kemokina, proteina koji kontroliraju apoptozu te sekrecije proupalnih citokina iz stanica prirođene imunosti. Klinički se interferonopatije najčešće manifestiraju vaskulopatijama ekstremiteta i pluća, nastankom fibroznih promjena, nastankom kožnih promjena nalik na ozebline, intrakranijalnim kalcifikacijama i miozitisom. Primjeri interferonopatija jesu Aicardi-Goutièresin sindrom zbog mutacije gena TREX1 koji je uključen u popravak oštećenja DNK, pri čemu zbog mutacije dolazi do hiperprodukcije IFN-a tipa I; zatim teški vaskulitis s početkom u dojenačkoj dobi zbog mutacije u genu STING (stimulator interferonskih gena) poznat pod nazivom SAVI (engl. STING-associated vasculopathy with onset in infancy); kronična neutrofilna dermatoza s lipodistrofijom i vrućicom poznata pod akronimom CANDLE (engl. Chronic atypical neutrophilic dermatosis with lipodystrophy and elevated temperature). U liječenju se rabe inhibitori JAK-a.

Ubikvitinopatije ili NF- $\kappa$ Bpatije jesu poremećaji koji zahvaćaju jednu ili više molekula koje se nazivaju ubikvitini. Ubikvitini su bjelančevine koje se vežu na druge proteine i time obilježavaju stanične proteine koji će se razgraditi, a važni su i za stabilnost, funkciju i unutarstanični položaj velikog broja proteina. Ovaj se proces naziva ubikvitinacija. Suprotan proces, kojim se molekule ubikvitina uklanjaju s proteina, naziva se deubikvitinacija. LUBAC (engl. Linear ubiquitin chain assembly complex) jest proteinski kompleks što se sastoji od proteina HOP, HOIL-1 i SHARPIN, koji imaju funkciju ubikvitina, i djeluje tako što aktivira signalni put NF- $\kappa$ B. Mutacije u genu za LUBAC dovode do autoinflamacije, imunodeficijencije i miopatije. Molekule A20 i OTULIN imaju funkciju deubikvitinaza i inhibiraju signalni put NF- $\kappa \mathrm{B}$, a mutacije dovode do autoinflamacije: haploinsuficijencija A20 i otulipenija (15, 16). Budući da su, dakle, ubikvitinopatije poremećaji koji su usko vezani uz abnormalnosti signalnog puta

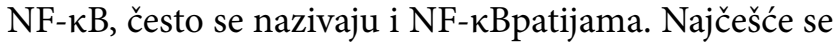
manifestiraju nastankom granuloma, ulceracija, uveitisa te imunodeficijencijom. Terapijski pristup u ovim bolestima temelji se na primjeni inhibitora TNF- $\alpha$ pa se katkad označuju i kao TNF-apatije.

Komplementopatije skupina su poremećaja u kojima dolazi do neprimjerene aktivacije komplementa i neki od tih poremećaja također se ubrajaju u autoinflamatorne bolesti (17). Kao primjer može se navesti atipični 
TABLE 3 a. Eurofever/PRINTO classification criteria for hereditary recurrent fevers (modified according to reference No. 19) TABLICA 3. a. Eurofeverovi/PRINTO-ovi klasifikacijski kriteriji za nasljedne periodične vrućice

(prilagodeno prema referenciji 19.)

\begin{tabular}{|c|c|c|c|}
\hline FMF & MKD & TRAPS & CAPS \\
\hline $\begin{array}{l}\text { Presence of a pathogenic or } \\
\text { potentially pathogenic variant } \\
\text { in the MEFV gene and at least } \\
\text { one of the following criteria: } \\
\text { / Prisutnost patogene ili } \\
\text { vjerojatno patogene varijante } \\
\text { u genu MEFV uz } \\
\text { zadovoljavanje barem jednog } \\
\text { od četiriju kriterija: } \\
\text { - febrile episodes lasting up to } \\
3 \text { days / febrilne epizode u } \\
\text { trajanju od jednog do tri } \\
\text { dana } \\
\text { - arthritis / artritis } \\
\text { - chest pain / bol u prsima } \\
\text { abdominal pain / bol u } \\
\text { trbuhu }\end{array}$ & $\begin{array}{l}\text { Presence of a pathogenic or } \\
\text { potentially pathogenic variant in } \\
\text { the MVK gene and at least one of } \\
\text { the following criteria: } \\
\text { / Prisutnost patogene ili vjerojatno } \\
\text { patogene varijante u genu } M V K \\
\text { uz još najmanje jedan kriterij: } \\
\text { - gastrointestinal symptoms } \\
\text { / gastrointestinalni simptomi } \\
\text { - neck lymphadenopathy } \\
\text { / limfadenopatija vrata } \\
\text { - aphthous stomatitis } \\
\text { / aftozni stomatitis }\end{array}$ & $\begin{array}{l}\text { Presence of a pathogenic or } \\
\text { potentially pathogenic variant } \\
\text { in the TNFRSF1A gene and at } \\
\text { least one of the following } \\
\text { criteria: } \\
\text { / Prisutnost patogene ili } \\
\text { vjerojatno patogene varijante } \\
\text { u genu TNFRSF1A uz još } \\
\text { najmanje jedan kriterij: } \\
\text { - episodic fever lasting at least } \\
\text { for } 7 \text { days / febrilne epizode } \\
\text { u trajanju od } 7 \text { dana ili dulje } \\
\text { - myalgia / mialgija } \\
\text { - migrating rash } \\
\text { / migrirajući osip } \\
\text { - periorbital edema } \\
\text { / periorbitalni edemi } \\
\text { - positive family history } \\
\text { / pozitivna obiteljska } \\
\text { anamneza }\end{array}$ & $\begin{array}{l}\text { Presence of a pathogenic or } \\
\text { potentially pathogenic variant } \\
\text { in the NLRP3 gene and at least } \\
\text { one of the following criteria: } \\
\text { / Prisutnost patogene ili } \\
\text { vjerojatno patogene varijante } \\
\text { u genu NLRP3 uz još najmanje } \\
\text { jedan kriterij: } \\
\text { - urticaria-like rash } \\
\text { / osip nalik na urtikarijski } \\
\text { - red eye (conjunctivitis, } \\
\text { episcleritis, uveitis) } \\
\text { / crveno oko (konjunktivitis, } \\
\text { episkleritis, uveitis) } \\
\text { - sensorineural hearing loss } \\
\text { / senzorineuralni gubitak } \\
\text { sluha }\end{array}$ \\
\hline $\begin{array}{l}\text { Presence of a variant not } \\
\text { proven to be pathogenic or } \\
\text { potentially pathogenic and at } \\
\text { least two of the following } \\
\text { criteria: } \\
\text { / Prisutnost varijante koja nije } \\
\text { dokazano patogena ili } \\
\text { vjerojatno patogena uz } \\
\text { zadovoljavanje barem dvaju od } \\
\text { četiriju kriterija: } \\
\text { - febrile episode lasting up to } \\
3 \text { days / febrilne epizode } \\
\text { u trajanju od jednog do tri } \\
\text { dana } \\
\text { - arthritis / artritis } \\
\text { - chest pain / bol u prsima } \\
\text { - abdominal pain } \\
\text { / bol u trbuhu }\end{array}$ & & $\begin{array}{l}\text { Presence of a variant not } \\
\text { proven to be pathogenic or } \\
\text { potentially pathogenic and at } \\
\text { least two of the following } \\
\text { criteria: } \\
\text { / Prisutnost varijante koja nije } \\
\text { dokazano patogena ili } \\
\text { vjerojatno patogena uz } \\
\text { zadovoljavanje barem dvaju } \\
\text { kriterija: } \\
\text { - episodic fever lasting at least } \\
\text { for } 7 \text { days / febrilne epizode } \\
\text { u trajanju od } 7 \text { dana ili dulje } \\
\text { - myalgia / mialgija } \\
\text { - migrating rash } \\
\text { / migrirajući osip } \\
\text { - periorbital edema } \\
\text { / periorbitalni edemi } \\
\text { - positive family history } \\
\text { / pozitivna obiteljska } \\
\text { anamneza }\end{array}$ & $\begin{array}{l}\text { Presence of a variant not } \\
\text { proven to be pathogenic or } \\
\text { potentially pathogenic and at } \\
\text { least two of the following } \\
\text { criteria: } \\
\text { / Prisutnost varijante koja nije } \\
\text { dokazano patogena ili } \\
\text { vjerojatno patogena uz } \\
\text { zadovoljavanje barem dvaju } \\
\text { kriterija: } \\
\text { - urticaria-like rash } \\
\text { / osip nalik na urtikarijski } \\
\text { - red eye (conjunctivitis, } \\
\text { episcleritis, uveitis) } \\
\text { / crveno oko (konjunktivitis, } \\
\text { episkleritis, uveitis) } \\
\text { - sensorineural hearing loss } \\
\text { / senzorineuralni gubitak } \\
\text { sluha }\end{array}$ \\
\hline
\end{tabular}

Legend / Legenda: FMF: familial Mediterranean fever / obiteljska mediteranska vrućica; MKD: mevalonate kinase deficiency / manjak mevalonat kinaze; TRAPS: tumor necrosis factor receptor-associated periodic syndrome / periodične vrućice vezane uz receptor čimbenika tumorske nekroze; CAPS: cryopyrin-associated periodic syndromes / kriopirinski sindromi periodične vrućice

PAPA syndrome and NLRC4-associated macrophage activation syndrome (NLRC4-MAS).

\section{Periodic fever syndromes}

Periodic or recurrent fever syndromes are autoinflammatory disorders defined by three or more episodes of unexplained/non-infectious fever (i.e., body temperature $\geq 38^{\circ} \mathrm{C}$ ) in a 6-month period with symptom-free intervals between episodes lasting 7 or more days. In most cases the fever is greater than $39^{\circ} \mathrm{C}$, and symptom-free intervals can be regular and irregular (18). Between fever episodes, the affected children are usually well, without growth and development impair- hemolitičko-uremijski sindrom (aHUS) koji je uzrokovan mutacijama u genima $C F H$, THBD, CFI i CD46 pri čemu dolazi do hemolitičke anemije, trombocitopenije i zatajenja bubrega.

\section{PRIKAZ NAJČEŠĆIH \\ AUTOINFLAMATORNIH BOLESTI PREMA PATOGENETSKIM MEHANIZMIMA NASTANKA}

\section{Inflamasomopatije}

U skupinu inflamasomopatija ubrajaju se monogenski sindromi periodičnih vrućica (obiteljska medite- 
TABLE 3 b. Eurofever/PRINTO clinical classification criteria for hereditary recurrent fevers and PFAPA (modified according to reference No. 19)

TABLICA 3. b. Eurofeverovi/PRINTO-ovi klinički kriteriji za nasljedne periodične vrućice i sindrom PFAPA (prilagodeno prema referenciji 19.)

\begin{tabular}{|c|c|c|c|c|}
\hline FMF & MKD & TRAPS & CAPS & PFAPA \\
\hline $\begin{array}{l}\text { At least } 6 \text { out of } 9 \text { criteria } \\
\text { need to be fulfilled. } \\
\text { Presence of: } \\
\text { / Ispunjavanje najmanje } \\
\text { šest od ukupno devet } \\
\text { kriterija. } \\
\text { Prisutnost: } \\
\text { - Eastern Mediterranean } \\
\text { origin } \\
\text { / istočnomediteranskog } \\
\text { podrijetla } \\
\text { - arthritis / artritisa } \\
\text { - chest pain } \\
\text { / boli u prsima } \\
\text { - abdominal pain } \\
\text { / boli u trbuhu }\end{array}$ & $\begin{array}{l}\text { At least } 3 \text { out of } 6 \text { criteria } \\
\text { need to be fulfilled. } \\
\text { Presence of: } \\
\text { / Ispunjavanje najmanje } \\
\text { triju od šest kriterija. } \\
\text { Prisutnost: } \\
\text { - disease onset in the first } \\
\text { year of life / početka } \\
\text { bolesti prije navršene } \\
\text { prve godine života } \\
\text { - gastrointestinal } \\
\text { symptoms } \\
\text { / gastrointestinalnih } \\
\text { simptoma } \\
\text { - painful lymph nodes } \\
\text { / bolnih limfnih čvorova } \\
\text { - aphthous stomatitis } \\
\text { / aftoznog stomatitisa } \\
\text { - maculopapular rash } \\
\text { / makulopapuloznog } \\
\text { osipa } \\
\text { - noticable disease } \\
\text { triggers such as } \\
\text { infection, } \\
\text { immunization, trauma, } \\
\text { stress / zamijećenih } \\
\text { okidača (trigeri) pojave } \\
\text { bolesti kao što su } \\
\text { infekcija, cijepljenje, } \\
\text { ozljeda } \\
\text { ili stres }\end{array}$ & $\begin{array}{l}\text { Five (5) or more points. } \\
\text { Presence of: } \\
\text { / Ostvarivanje } 5 \text { ili više } \\
\text { bodova. } \\
\text { Prisutnost: } \\
\text { - episodes of fever lasting } 7 \\
\text { or more days ( } 2 \text { pts) } \\
\text { / epizode vrućice u } \\
\text { trajanju od } 7 \text { ili više dana } \\
\text { ( } 2 \text { boda) } \\
\text { - febrile episodes lasting } 5 \\
\text { or } 6 \text { days ( } 1 \text { pt) / epizode } \\
\text { vrućice u trajanju od } 5 \\
\text { do } 6 \text { dana ( } 1 \text { bod) } \\
\text { - myalgia ( } 1 \text { pt) } \\
\text { / mialgija ( } 1 \text { bod) } \\
\text { - migrating rash ( } 1 \text { pt) } \\
\text { / migrirajući osip ( } 1 \text { bod) } \\
\text { - periorbital edema ( } 1 \text { pt) } \\
\text { / periorbitalni edemi } \\
\text { ( } 1 \text { bod) } \\
\text { - positive family history } \\
\text { ( } 1 \text { pt) / pozitivna } \\
\text { obiteljska anamneza } \\
\text { ( } 1 \text { bod) }\end{array}$ & $\begin{array}{l}\text { At least } 2 \text { out of } 5 \\
\text { criteria need to be } \\
\text { fulfilled. } \\
\text { Presence of: } \\
\text { / Ispunjavanje } \\
\text { najmanje dvaju od pet } \\
\text { kriterija. } \\
\text { Prisutnost: } \\
\text { - urticaria-like rash } \\
\text { / osipa nalik na } \\
\text { urtikarijski } \\
\text { - cold- or stress- } \\
\text { induced disease } \\
\text { episodes / epizode } \\
\text { pojave bolesti } \\
\text { potaknute } \\
\text { hladnoćom ili } \\
\text { stresom } \\
\text { - sensorineural } \\
\text { hearing loss } \\
\text { / senzorineuralnoga } \\
\text { gubitka sluha } \\
\text { - chronic aseptic } \\
\text { meningitis } \\
\text { / kroničnog } \\
\text { aseptičnog } \\
\text { meningitisa } \\
\text { - bone anomalies } \\
\text { (abnormal } \\
\text { epiphyseal growth or } \\
\text { prominent forehead) } \\
\text { / anomalije skeleta } \\
\text { (prekomjerni rast } \\
\text { epifiza kostiju ili } \\
\text { prominentno čelo) }\end{array}$ & $\begin{array}{l}\text { Seven (7) out of } \\
8 \text { criteria need to be } \\
\text { fulfilled. } \\
\text { Presence of: } \\
\text { / Ispunjavanje } \\
\text { najmanje sedam } \\
\text { od osam kriterija. } \\
\text { Prisutnost: } \\
\text { - tonsillo-pharyngitis } \\
\text { / tonzilofaringitisa } \\
\text { - recurring febrile } \\
\text { episodes lasting 3-6 } \\
\text { days / ponavljanih } \\
\text { febrilnih epizoda } \\
\text { koje traju } \\
3 \text { - 6 dana } \\
\text { - neck lymphadenitis } \\
\text { / limfadenitisa vrata } \\
\text { - periodicity } \\
\text { / periodičnosti } \\
\text { pojavljivanja }\end{array}$ \\
\hline $\begin{array}{l}\text { Absence of: } \\
\text { / Odsutnost: } \\
\text { - aphthous stomatitis } \\
\text { / aftoznog stomatitisa } \\
\text { - urticarial rash } \\
\text { / urtikarijskog osipa } \\
\text { - maculopapular rash } \\
\text { / makulopapuloznog } \\
\text { osipa } \\
\text { - painful lymph nodes } \\
\text { / bolnih limfnih } \\
\text { čvorova }\end{array}$ & & $\begin{array}{l}\text { Absence of: } \\
\text { / Odsutnost: } \\
\text { - aphthous stomatitis ( } 1 \mathrm{pt}) \\
\text { / aftoznog stomatitisa } \\
\text { (1 bod) } \\
\text { - tonsillopharyngitis (1 pt) } \\
\text { / tonzilofaringitisa (1 } \\
\text { bod) }\end{array}$ & & $\begin{array}{l}\text { Absence of: } \\
\text { / Odsutnost: } \\
\text { - diarrhea / proljeva } \\
\text { - chest pain } \\
\text { / boli u prsima } \\
\text { - rash / osipa } \\
\text { - arthritis / artritisa }\end{array}$ \\
\hline
\end{tabular}

Legend / Legenda: FMF: familial Mediterranean fever / obiteljska mediteranska vrućica; MKD: mevalonate kinase deficiency / manjak mevalonat kinaze; TRAPS: tumor necrosis factor receptor-associated periodic syndrome / periodične vrućice vezane uz receptor čimbenika tumorske nekroze; CAPS: cryopyrin-associated periodic syndromes / kriopirinski sindromi periodične vrućice; PFAPA: periodic fever, aphthous stomatitis, pharyngitis, and cervical adenitis / sindrom periodične vrućice, aftoznog stomatitisa, faringitisa $i$ adenitisa

ment. Leukocytosis and increased acute phase reactants are characteristic laboratory findings during febrile episodes; these findings, as well as other symptoms, diminish as the fever drops, or within 4 days. Disease onset usually occurs in the first decade, a positive family history is common, and in some cases ethnic origin is also an importan factor (e.g., Eastern ranska vrućica, manjak mevalonat kinaze, periodična vrućica vezana uz receptor TNF- $\alpha$, kriopirinski sindromi periodične vrućice), što su prvi opisani primjeri autoinflamatornih bolesti, zatim sindrom DIRA, Majeedov sindrom te skupina bolesti koje su poznate pod zajedničkim nazivom rezistentne inflamasomopatije, kamo pripadaju sindrom PAPA i sindrom aktivaci- 
TABLE 4. Comparative view of disorders within the cryopyrin associated periodic syndromes

(made according to reference No. 21)

TABLICA 4. Usporedni prikaz kliničkog spektra poremećaja u sklopu kriopirinskih sindroma periodične vrućice (izradeno prema podatcima iz referencije 21.)

\begin{tabular}{|c|c|c|c|}
\hline & FCAS & MWS & CINCA/NOMID \\
\hline $\begin{array}{l}\text { Clinical features } \\
\text { / Kliničke značajke }\end{array}$ & $\begin{array}{l}\text { - cold-induced rash } \\
\text { / osip potaknut hladnoćom } \\
\text { - arthralgia / artralgija } \\
\text { - myalgia / mialgija } \\
\text { - conjunctivits / konjunktivitis } \\
\text { - lack of energy / umor } \\
\text { - headache / glavobolja } \\
\text { - short-lasting episodes of fever } \\
\text { (12-24 hours) } \\
\text { / kratkotrajne epizode vrućice } \\
\text { u trajanju od } 12 \text { do } 24 \text { sata }\end{array}$ & $\begin{array}{l}\text { - cold-induced rash } \\
\text { / osip potaknut hladnoćom } \\
\text { - arthralgia or arthritis } \\
\text { / artralgija ili artritis } \\
\text { - myalgia / mialgija } \\
\text { - conjunctivitis / konjunktivitis } \\
\text { - lack of energy / umor } \\
\text { - headache / glavobolja } \\
\text { - fever lasting 2-3 days } \\
\text { / epizode vrućice u trajanju } \\
\text { od } 2 \text { do } 3 \text { dana } \\
\text { - progressive hearing loss } \\
\text { / progresivni gubitak sluha } \\
\text { - kidney failure } \\
\text { / zatajenje bubrega }\end{array}$ & $\begin{array}{l}\text { - rash / osip } \\
\text { - knee-, ankle-, elbow-, and wrist- } \\
\text { deforming arthropathy with } \\
\text { contracture development } \\
\text { / artropatija s deformitetima koljena, } \\
\text { gležnjeva, laktova i zapešća uz razvoj } \\
\text { kontraktura } \\
\text { - short stature, short arms and fingers, } \\
\text { macrocranium / nizak rast uz kratke } \\
\text { ruke i prste te makrokranij } \\
\text { - chronic aseptic meningitis } \\
\text { (vomiting, headache, seizures, } \\
\text { hydrocephalus, brain and optic nerve } \\
\text { atrophy, blindness) / kronični } \\
\text { aseptični meningitis (povraćanje, } \\
\text { glavobolje, konvulzije, hidrocefalus, } \\
\text { atrofija mozga i vidnog živca, } \\
\text { sljepoća) } \\
\text { - uveitis } \\
\text { - intermittent fever } \\
\text { / intermitentni febriliteti } \\
\text { - progressive hearing loss } \\
\text { / progresivni gubitak sluha } \\
\text { - kidney failure / zatajenje bubrega }\end{array}$ \\
\hline $\begin{array}{l}\text { Symptom duration } \\
\text { / Trajanje simptoma }\end{array}$ & $\begin{array}{l}\text { Less than } 24 \text { hours } \\
\text { / najčešće kraće od } 24 \\
\text { sata }\end{array}$ & Daily / svaki dan & Daily / svaki dan \\
\hline $\begin{array}{l}\text { Symptom onset } \\
\text { / Početak simptoma }\end{array}$ & $<20$ years $/<20$ godina & $<6$ months $/<6$ mjeseci & infancy / novorođenačka dob \\
\hline Outcome / Posljedice & $\begin{array}{l}\text { limited daily activites } \\
\text { / ograničenje u dnevnim } \\
\text { aktivnostima }\end{array}$ & $\begin{array}{l}\text { - limited daily activites } \\
\text { / ograničenje u dnevnim } \\
\text { aktivnostima } \\
\text { - sensorineural hearing loss } \\
\text { / senzorineuralni gubitak sluha } \\
\text { - amyloidosis and kidney failure } \\
\text { / amiloidoza sa zatajenjem } \\
\text { bubrega }\end{array}$ & $\begin{array}{l}\text { - development retardation } \\
\text { / zaostajanje u razvoju } \\
\text { - sensorineural hearing loss } \\
\text { / senzorineuralni gubitak sluha } \\
\text { - blindness / sljepoća } \\
\text { - amyloidosis and kidney failure } \\
\text { / amiloidoza sa zatajenjem bubrega }\end{array}$ \\
\hline
\end{tabular}

Legend / Legenda: FCAS: familial cold autoinflammatory syndrome / obiteljski autoinflamatorni sindrom uzrokovan hladnoćom; WS: Muckle-Wells syndrome / Muckle-Wellsov sindrom; NOMID/CINSA: neonatal onset multisystem inflammatory disease / chronic infantile neurologic cutaneous articular syndrome / multisustavna inflamatorna bolest s početkom u novorođenačkoj dobi

Mediterranean, Middle East: Turks, Arabs; Southern Europe: Italians, Greeks, Spaniards). Febrile episodes in periodic fever syndromes are classified as short-lasting (24-48 h; familial Mediterranean fever), mediumlength ( 4 to 7 days; mevalonate kinase deficiency), and long-lasting (TNF-receptor-associated periodic fever syndrome) (19).

In March 2017, at a Consensus Conference held in Genoa, an expert group consisting of clinicians and geneticists established a new set of classification and clinical criteria for inherited periodic fever syndromes and PFAPA syndrome (19). The new criteria, known as the Eurofever/PRINTO (Pediatric Rheumatology International Trials Organization) criteria, are used in clinical and epidemiological research and are shown in Tables je makrofaga povezan s inflamasomom NLRC4 (engl. NLRC4-associated macrophage activation syndrome NLRC4-MAS).

\section{Sindromi periodičnih vrućica}

Sindromi periodičnih ili rekurentnih vrućica jesu autoinflamatorne bolesti obilježene ponavljanim febrilnim epizodama u odsutnosti infekcije, pri čemu je za zadovoljavanje definicije potrebno imati bolesnika s tri ili više epizoda vrućice $\geq 38^{\circ} \mathrm{C}$ u razmaku većem od 7 dana u periodu od minimalno 6 mjeseci. Vrućica je nerijetko viša od $39^{\circ} \mathrm{C}$, a intervali između febriliteta mogu biti pravilni ili nepravilni (18). Između epizoda febriliteta dijete je obično dobro i normalno raste. Tijekom epizoda febriliteta prisutni su leukocitoza i povi- 
$3 a$ and $3 b$. According to the criteria, each disease needs a confirmed gene mutation. If a gene mutation is pathogenic or its pathogenicity is highly probable, fewer clinical parameters need to be fulfilled for the diagnosis; the opposite is the case if the mutation is not proven to be pathogenic or is unlikely pathogenic. The aforementioned expert group also established clinical criteria that are not based on gene testing and can be used in everyday clinical practice. Since cryopyrin-associated periodic syndromes (CAPS) manifest in a broad clinical spectrum from mild to severe conditions (in order of severity: familial cold autoinflammatory syndrome (FCAS), Muckle-Wells syndrome, neonatal-onset multisystem inflammatory disease / chronic infantile neurologic cutaneous articular syndrome (NOMID/CINCA)), they are summarized in Table $4(20,21)$.

Colchicine is the basis of FMF management as it reduces leukocyte motility and phagocytosis, in addition to preventing the development of amyloidosis and proteinuria. Anakinra, an IL-1 receptor antagonist, is an alternative treatment option in refractory cases; other options are TNF- $\alpha$ and $\alpha$-interferon inhibitors (22). Mevalonate kinase deficiency is treated with glucocorticoids, anakinra, TNF- $\alpha$ inhibitors and simvastatin (23). Glucocorticoids and biologics such as TNF- $\alpha$ inhibtors (e.g., etanercept) and anakinra are used in the treatment of TRAPS (24), and IL-1 inhibitors (anakinra, canakinumab) are used for treating CAPS $(20,21)$.

Although not a monogenic disease like the other mentioned conditions, PFAPA syndrome (periodic fever, aphthous stomatitis, pharyngitis, cervical adenitis) is traditionally a member of the periodic fever syndrome family, and it is in fact the most common type of periodic fever syndromes. Effective treatment options are glucocorticoids in a solitary dose of 0.1 to 1 $\mathrm{mg} / \mathrm{kg}$, tonsillectomy, or anakintra (25). In most cases, the condition spontaneously resolves between the $6^{\text {th }}$ and $8^{\text {th }}$ year of life.

\section{DIRA (IL-1 receptor antagonist deficiency) and Majeed syndrome}

DIRA syndrome is an autosomal recessive disease caused by a mutation in the IL1RN gene responsible for coding the IL-1 receptor antagonist that normally controls the inflammatory activity of proinflammatory cytokine IL-1 (26). The result is a dysregulation of cytokine pathways and an amplified inflammatory response. This condition most often presents with skin (usually pustular) and bone (sterile bone inflammation) manifestations that occur within the first several days of life; cerebral vasculitis, pulmonary hemosiderosis with lung fibrosis, hypotonia, and impaired growth and development can also occur. Inflammatory markers are increased and usually there is no fever. IL-1 inhibitors (anakinra) are used for treatment. šeni reaktanti akutne faze upale uz normalizaciju laboratorijskih nalaza i prestanak simptoma nakon završetka ili u 4 dana od završetka epizode febriliteta. Početak bolesti najčešće je u prvih 10 godina života. Obiteljska anamneza često je pozitivna, a za neke bolesti bitno je i etničko podrijetlo bolesnika (npr., istočni Mediteran, srednji Istok: Turci, Arapi, južna Europa: Talijani, Grci, Španjolci). Prema duljini febrilnih epizoda, mogu se podijeliti na one s kratkim epizodama (od 24 do 48 sati) kao što je obiteljska mediteranska vrućica, na one sa srednje dugim epizodama vrućice (od 4 do 7 dana) kao što je nedostatak mevalonat kinaze te na one s prolongiranim febrilnim epizodama kao što je periodična vrućica vezana uz receptor TNF- $\alpha$ (19).

Skupina od 33 eksperta iz područja autoinflamatornih bolesti (uključujući kliničare i genetičare) na konsenzusnoj je konferenciji, održanoj u Genovi u ožujku 2017., donijela klasifikacijske i kliničke kriterije za nasljedne periodične vrućice i sindrom PFAPA (19). Ti se novi Eurofeverovi/PRINTO-ovi (engl. Paediatric Rheumatology INternational Trials Organisation) klasifikacijski kriteriji rabe pri kliničkim i epidemiološkim istraživanjima. Prikazani su na tablicama 3. a i 3. b. Zajedničko im je da za svaku pojedinu bolest iz ove skupine iziskuju potvrđenu mutaciju u genu vezanom uz nastanak bolesti. Ako je dokazana patogena ili vjerojatno patogena varijanta u određenom genu, potrebno je zadovoljiti manji broj ostalih kriterija nego pri mutaciji koja nije dokazano patogena ili vjerojatno patogena. Navedena skupina eksperata donijela je i kliničke kriterije koji se rabe za postavljanje dijagnoze kod pojedinog bolesnika u svakodnevnom radu, a ne temelje se na dokazanoj genskoj mutaciji. Budući da kriopirinski sindromi periodične vrućice (engl. Cryopyrin-associated periodic syndromes - CAPS) uključuju spektar bolesti od blagih do teških (prema težini: obiteljski autoinflamatorni sindrom uzrokovan hladnoćom (engl. Familial cold autoinflammatory syndrome - FCAS), Muckle-Wellsov sindrom i multisustavna inflamatorna bolest s početkom u novorođenačkoj dobi (engl. Neonatal onset multisystem inflammatory disease / Chronic infantile neurological cutaneous articular syndrome NOMID/CINCA), njihove su značajke sažete na tablici 4. $(20,21)$.

Temelj liječenja obiteljske mediteranske vrućice (engl. Familial mediterranean fever - FMF) jest primjena kolhicina koji djeluje tako što usporava motilitet leukocita i fagocitozu te prevenira razvoj amiloidoze i proteinurije. U rezistentnih oblika bolesti alternativa je antagonist receptora za interleukin 1 , odnosno anakinra, a ostali modaliteti liječenja uključuju inhibitore TNF- $\alpha$ i $\alpha$-interferon (22). Pri liječenju manjka mevalonat kinaze primjenjuju se glukokortikoidi, anakinra, inhibitori TNF- $\alpha$ te simvastatin (23). Liječenje periodične vrućice vezane uz receptor TNF-a (engl. Tumor ne- 
Majeed syndrome is also an autosomal recessive autoinflammatory disease, monogenic in nature and caused by a mutation in the LPIN2 gene, a coding gene for lipin-2 protein (27). The pathophysiological effects of changes in lipin-2 acitivity are unknown. Majeed syndrome usually occurs in the first 2 years of life with cardinal clinical manifestations such as recurrent fever, skin changes (pustular changes or changes similar to Sweet syndrome), bone inflammation (chronic recurring osteomyelitis), and anemia. Patients can be treated with non-steroidal anti-inflammatory agents, glucocorticoids and IL-1 inhibitors.

\section{PAPA syndrome}

PAPA is an acronym for the classical clinical triad of this syndrome: pyogenic sterile arthritis, pyoderma gangrenosum, and acne. The condition is inherited in an autosomal dominant fashion. It results from a mutation in the PSTPIP1 gene which codes a pyrin-binding adaptor protein; this mutation leads to an overproduction of IL-1 (28). This disease usually manifests in the first decade of life. Fever is rarely present, leukocytosis with neutrophilia is a common finding. A recurrent, pyogenic yet sterile, and erosive arthritis is the first manifestation. It begins in early childhood, either spontaneously or after a minor trauma, and it affects the elbows, knees, and ankles. Arthritis continues into adulthood, leading to joint destruction. Skin changes first appear in adolescence as prominent cystic acne or pyoderma gangrenosum. IL-1 inhibitors (anakinra) are efficent in the treatment of pyogenic arthritis, and anti-TNF agents combined with retinoids in the treatment of skin changes.

\section{Interferonopathies}

Clinically, the most important interferonopathies are Aicardi-Goutières syndrome, severe neonatal STING-associated vasculopathy with onset in infancy, and a group of diseases known as proteasome-associated autoinflammatory syndrome (PRAAS).

\section{Aicardi-Goutières syndrome}

Aicardi-Goutières syndrome is a genetically heterogeonus disorder caused by mutations in one out of seven different genes resulting in an overproduction of type I interferon (29). It most often affects the central nervous system and the skin. There are two types of the disease - early- and late-onset. The early-onset type is more severe; symptoms manifest in the perinatal period and include neurological disorders (involuntary movements, tremor, feeding difficulties), hepatosplenomegaly, increased liver enzymes, and thrombocytopenia. Late-onset disease occurs after several weeks or months of normal development manifesting crosis factor receptor-associated periodic syndrome TRAPS) temelji se na primjeni glukokortikoida i biološke terapije (inhibitori TNF- $\alpha$ kao što je etanercept $i$ anakinra) (24). Liječenje kriopirinskih sindroma periodične vrućice (engl. Cryopyrin-associated periodic syndromes - CAPS) provodi se inhibitorima interleukina 1 (anakinra i kanakinumab) $(20,21)$.

$\mathrm{U}$ sindrome periodičnih vrućica tradicionalno se ubraja i sindrom PFAPA (engl. Periodic fever, aphthous stomatitis, pharyngitis and cervical adenitis), odnosno sindrom periodične vrućice, aftoznog stomatitisa, faringitisa i adenitisa koji je najčešći sindrom periodičnih vrućica, premda se ne radi o monogenskoj autoinflamatornoj bolesti za razliku od prije nabrojenih. Pri liječenju mogu biti učinkovite jednokratna primjena glukokortikoida u dozi od 0,1 do $1,0 \mathrm{mg} / \mathrm{kg}$, tonzilektomija ili anakinra (25). U većine bolesnika epizode spontano prestanu u dobi od 6 do 8 godina.

\section{Sindrom DIRA (engl. Deficiency of the \\ IL-1-receptor antagonist) i Majeedov sindrom}

Sindrom DIRA jest autosomno recesivna bolest uzrokovana mutacijom u genu IL1RN koji kodira za antagonist receptora za IL-1 i u normalnim uvjetima ograničava aktivnost proupalnog citokina IL-1 (26). Posljedično dolazi do poremećaja regulacije citokinske signalizacije i pojačanja upalnog odgovora. Najčešće su kožne (obično pustularne) i koštane manifestacije bolesti (sterilne upale kostiju) koje se pojavljuju već u prvim danima života, a uz to se mogu pojaviti cerebralni vaskulitis, plućna hemosideroza s razvojem fibroze pluća, hipotonija, nenapredovanje djeteta. Upalni su parametri povišeni, a vrućice obično nema. Pri liječenju se rabi inhibitor IL-1 (anakinra).

Majeedov je sindrom autosomno recesivna monogenska autoinflamatorna bolest uzrokovana mutacijom u genu LPIN2 koji kodira za protein lipin 2 (27). Nije jasno na koji način promjene $\mathrm{u}$ aktivnosti ovog proteina uzrokuju nastanak bolesti. Bolest obično započinje prije navršene 2. godine. Glavna su obilježja bolesti ponavljane epizode vrućice, upala kože (promjene na koži pustularne su ili odgovaraju Sweetovu sindromu) i kostiju (kronični rekurentni osteomijelitis) te anemija. U liječenju se rabe nesteroidni protuupalni lijekovi, glukokortikoidi i inhibitor IL-1.

\section{Sindrom PAPA}

Naziv sindroma PAPA akronim je trijasa simptoma koji se u njemu javljaju: piogeni sterilni artritis, gangrenozna pioderma i akne. Bolest se nasljeđuje autosomno dominantno, a rezultat je mutacije u genu PSTPIP1 koji kodira adaptorski protein što se može vezati za pirin, a to dovodi do prekomjerne produkcije IL-1 (28). Bolest najčešće počinje u prvom desetljeću života. Vrućica je ovdje rijetko prisutna, a u nalazima 
with psychomotor retardation, microcephaly, and episodes of encephalopathy marked with irritability, inconsolable crying, and feeding difficulties. Intermittent fever and convulsions can also occur. Ultimately the condition results in permanent neurological damage such as intellectual deficits, hand muscle spasticity, core muscle dystonia, and hypotonia. Leukodystrophy and brain calcifications develop. Vasculitis causes painful, red and swollen frostbite-like skin changes on the fingers, toes, and ears. Some patients have immune system disorders and develop systemic erythematosus lupus. Apart from symptomatic treatment, there were also trials of JAK-inhibitors (with variable results) and antiretroviral agents used for treating HIV infection.

\section{STING-associated vasculopathy with onset in infancy (SAVI)}

SAVI is an interferonopathy caused by an autosomal dominant mutation of the STING1 gene, an interferon gene stimulator (14). The skin and lungs are affected in most cases. Vasculopathy-induced skin changes develop in the first few months of life, usually affecting the face, nose, ears, fingers, and toes. These changes begin as skin discolorations which progress to ulcerations and finally to necrotising ulcers leading to scarring, nasal septum perforation, and finger or toe amputation. Interstitial lung disease occurs, leading to pulmonary fibrosis and respiratory insufficiency. Lymphadenopathy and intermittent fever can occur. JAK-inhibitors are the treatment of choice.

\section{Proteasome-associated autoinflammatory syndrome (PRAAS)}

An example from this spectrum of disorders is chronic neutrophilic dermatosis with lipodystrophy and fever (30). It is a disease caused by mutations in the proteasome subunit- encoding gene. Proteasomes are protein complexes responsible for eliminating intracellular protein detritus and foreign protein degradation. Proteasome dysfunction leads to accumulation of said detritus within the cell and interferon type I production. The disease manifests in the first few months of life, starting with frostbite-like skin changes, circular plaques, and erythematous edema. Fever is common. The skin changes are followed by lipodystrophy and, ultimately, joint changes. JAK-inhibitor trials are ongoing.

\section{Ubiquitinopathies}

These conditions are closely associated with NF-kB signaling pathway abnormalities (15). An example is Blau syndrome, an autosomal dominant disorder caused by a mutation in the NOD2 gene. The syndrome is characterized by a clinical triad - early-onset polyar- se često vidi leukocitoza s neutrofilijom. Najprije se pojavljuje artritis. Artritis je rekurentan, piogen, ali sterilan i erozivan, a započinje obično u ranoj dječjoj dobi, spontano ili nakon manje traume te zahvaća laktove, koljena i gležnjeve. Simptomi su prisutni do odrasle dobi, a dovode do destrukcije zglobova. Kožne promjene javljaju se u adolescenciji kao izražene cistične akne ili gangrenozna pioderma. Pri liječenju piogenog artritisa primjenjuje se inhibitor IL-1 (anakinra), a $\mathrm{u}$ liječenju kožnih manifestacija pripravci anti-TNF- $\alpha$ u kombinaciji s retinoidima.

\section{Interferonopatije}

Najvažnije interferonopatije jesu Aicardi-Goutièresin sindrom, teški vaskulitis s početkom u dojenačkoj dobi zbog mutacije u genu STING te skupina bolesti pod nazivom autoinflamatorni sindrom povezan s poremećajem funkcije proteasoma (engl. Proteasomeassociated autoinflammatory syndrome - PRAAS).

\section{Aicardi-Goutièresin sindrom}

Riječ je o genski heterogenoj bolesti uzrokovanoj mutacijama u jednom od sedam različitih gena zbog čega dolazi do prekomjernog stvaranja interferona tipa I (29). Najčešće su zahvaćeni središnji živčani sustav i koža. Postoje dva oblika bolesti - rani i kasni. U ranom obliku bolesti, koji je teži, simptomi se javljaju odmah nakon rođenja i uključuju neurološke poremećaje (nevoljne pokrete, tremor, poremećaje hranjenja), hepatosplenomegaliju, povišene jetrene enzime i trombocitopeniju. U kasnom obliku bolesti nakon nekoliko tjedana ili mjeseci normalnog razvoja dolazi do zaostajanja u psihomotoričkom razvoju, pojave mikrocefalije i epizoda encefalopatije tijekom koje su djeca izrazito razdražljiva uz neutješan plač i poremećaj hranjenja. Mogu se pojaviti intermitentni febriliteti i konvulzije. Naposljetku obično dolazi do trajnih neuroloških oštećenja koja se manifestiraju teškim intelektualnim poremećajima, spasticitetom mišića ruku, distonijom i hipotonijom mišića trupa. Dolazi do razvoja leukodistrofije i kalcifikata u mozgu. Promjene na koži nalikuju na ozebline. Uzrokovane su vaskulitisom, a manifestiraju se kao bolne, crvene i otečene promjene na prstima ekstremiteta i uškama. U nekih bolesnika dolazi i do imunosnih poremećaja i razvoja sustavnog eritemskog lupusa. Osim simptomatskog liječenja, u nekih su bolesnika primjenjivani inhibitori JAK-a s varijabilnim učinkom, kao i antiretrovirusni lijekovi koji se rabe u liječenju infekcije HIV-om.

\section{Teški vaskulitis s početkom u dojenačkoj dobi zbog mutacije u genu STING (engl. STING-associated vasculopathy with onset in infancy - SAVI)}

Ova interferonopatija uzrokovana je autosomno dominantnim mutacijama u genu STING1 koji je stimu- 
TABLE 5. Comparison of current and proposed new criteria for systemic juvenile idiopathic arthritis (sJIA) (modified according to references No. 31 and 32)

TABLICA 5. Usporedba postojećih i predloženih novih kriterija za sustavni oblik juvenilnog idiopatskog artritisa (sIIA) (prilagođeno prema referencijama 31. i 32.)

\begin{tabular}{|c|c|}
\hline $\begin{array}{l}\text { Current diagnostic criteria for sJIA } \\
\text { / Postojeći kriteriji za postavljanje dijagnoze sJIA }\end{array}$ & $\begin{array}{l}\text { Proposed new diagnostic criteria for sJIA } \\
\text { / Predloženi novi kriteriji za postavljanje dijagnoze sJIA }\end{array}$ \\
\hline $\begin{array}{l}\text { Arthritis associated with intermittent fever lasting for at least } 2 \text { weeks } \\
\text { and at least one of the following: } \\
\text { / Artritis udružen s intermitentnom vrućicom u trajanju } \\
\text { od najmanje } 2 \text { tjedna te barem jedan od ovih simptoma: } \\
\text { - macular or maculopapular rash / mrljasti ili makulopapulozni osip } \\
\text { - splenomegaly or hepatomegaly / splenomegalija ili hepatomegalija } \\
\text { - generalized lymphadenopathy / generalizirana limfadenopatija } \\
\text { - serositis / serozitis }\end{array}$ & $\begin{array}{l}\text { Fever of uknown origin }\left(39^{\circ} \mathrm{C} \text { or above daily with }\right. \\
\text { drops to } 37^{\circ} \mathrm{C} \text { or below) ocurring daily for at least } \\
3 \text { consecutive days and recurring for at least } 2 \text { weeks } \\
\text { / Vrućica nepoznata podrijetla (raste do } 39^{\circ} \mathrm{C} \text { ili više } \\
\text { jedanput na dan i pada na } 37^{\circ} \mathrm{C} \text { ili niže tijekom vršaka } \\
\text { febriliteta) prisutna svakog dana najmanje } 3 \text { dana } \\
\text { uzastopno, a ponavlja se tijekom najmanje } 2 \text { tjedna } \\
+ \\
2 \text { major criteria OR } 1 \text { major and } 1 \text { minor criterion } \\
/ 2 \text { glavna kriterija ILI } 1 \text { glavni i } 1 \text { sporedni kriterij }\end{array}$ \\
\hline $\begin{array}{l}\text { EXCLUSION CRITERIA: / ISKLJUČNI KRITERIJI: } \\
\text { - psoriasis (personal history or a first-degree relative) } \\
\text { / pozitivna osobna i/ili obiteljska anamneza na psorijazu u prvom koljenu } \\
\text { - arthritis in male patients older than } 6 \text { and HLA-B27+ / pojava artritisa } \\
\text { u dječaka nakon 6. godine s pozitivnim antigenom HLA-B27 } \\
\text { - ankylosing spondylitis, enthesitis-associated arthritis, enteropathy- } \\
\text { associated sacroiliitis, Reiter syndrome, acute anterior uveitis OR a } \\
\text { first-degree relative suffering from any of the mentioned conditions } \\
\text { / ankilozantni spondilitis, artritis pridružen entezitisu, sakroileitis s } \\
\text { upalnim crijevnim bolestima, Reiterov sindrom, ili akutan prednji uveitis, } \\
\text { ili pozitivna obiteljska anamneza na jednu od ovih bolesti u prvom koljenu } \\
\text { - positive rheumatoid factor (IgM RF) in at least two measurements } \\
\text { at least } 3 \text { months apart / pozitivan reumatoidni čimbenik (IgM RF) } \\
\text { najmanje u dva mjerenja u razmaku od tri mjeseca }\end{array}$ & $\begin{array}{l}\text { MAJOR CRITERIA: / GLAVNI KRITERIJI: } \\
\text { 1. non-fixed and disappearing erythematous rash } \\
\text { / eritematozni osip koji nije fiksan i iščezava } \\
\text { 2. arthritis / artritis }\end{array}$ \\
\hline & $\begin{array}{l}\text { MINOR CRITERIA: / SPOREDNI KRITERIJI: } \\
\text { 1. generalized lymphadenopathy and/or hepatomegaly } \\
\text { and/or splenomegaly / generalizirana limfadenopatija } \\
\text { i/ili hepatomegalija i/ili splenomegalija } \\
\text { 2. serositis / serozitis } \\
\text { 3. artrhralgia lasting for } 2 \text { weeks or more (without } \\
\text { arthritis) / artralgija u trajanju od } 2 \text { tjedna ili dulje } \\
\text { (u odsutnosti artritisa) } \\
\text { 4. leukocytosis ( } 15,000 / \mathrm{mm}^{2} \text { or more) and neutrophilia } \\
\text { / leukocitoza }\left(15.000 / \mathrm{mm}^{3} \text { ili veća) uz neutrofiliju }\right.\end{array}$ \\
\hline
\end{tabular}

ticular arthirits (tenosynovitis), uveitis (often panuveitis), and rash (in most cases erythematous scaling papules). Skin and eye changes manifest as non-caseous granulomas. Patients with otulipenia have panniculitis, arthritis, and diarrhea; those with A20-haploinsufficiency develop oral ulcerations, uveitis, and pathergy (trauma-induced sterile pustules). Patients with HOP and HOIL-1 defficiencies are immunodeficient and prone to bacterial and viral infections.

\section{Multifactorial inflammatory disease}

Systemic juvenile idiopathic arthritis (sJIA) and autoinflammatory bone disease manifesting with sterile inflammatory osteolytic lesions will be reviewed here.

\section{Systemic juvenile idiopathic arthritis (sJIA)}

According to the still current 1997 International League Against Rheumatism classification, sJIA is the most severe and most acute form of JIA, resulting from lator interferonskih gena (14). Bolest najčešće zahvaća kožu i pluća. Kožne promjene počinju se javljati u prvim mjesecima života zbog vaskulopatije. Obično zahvaćaju lice, nos, uške i prste ekstremiteta. Najprije se javlja diskoloracija kože, zatim ulceracije i naposljetku ulkusi zbog nekroze tkiva koji mogu uzrokovati nastanak ožiljaka, perforaciju nosnog septuma i dovesti do amputacije prstiju. Mogu se javiti intersticijska plućna bolest s dispnejom, razvoj plućne fibroze i respiratorne insuficijencije. Nalaze se i limfadenopatija i intermitentni febriliteti. Pri liječenju se primjenjuju inhibitori JAK-a.

\section{Autoinflamatorni sindrom povezan s poremećajem funkcije proteasoma}

Kao primjer bolesti iz ovog spektra može se navesti kronična neutrofilna dermatoza s lipodistrofijom i vrućicom (30). Riječ je o bolesti koja je uzrokovana mutacijama u genu koji kodira za podjedinice pro- 
genetic and environmental factor interactions. As innate immunity dysregulation plays an important role in the pathogenesis of sJIA, it differs from other forms of JIA which are autoimmune in nature (Table 5). According to the latest criteria by PRINTO established in 2019 , in order to be diagnosed with sJIA a patient needs to have a daily fever of $39^{\circ} \mathrm{C}$ or above that drops to $37^{\circ} \mathrm{C}$ or below for at least 3 days, recurring for at least 2 weeks (32). Apart from the fever, at least two major or one major and one minor criterion need to be fulfilled. Major criteria are non-fixed, vanishing, erythematous rash and arthritis. Minor criteria are generalized lymphadenopathy and/or hepato/splenomegaly; joint pain without arthritis lasting for at least 2 weeks; leukocytosis $(15,000 / \mathrm{mm} 3$ or above) with neutrophil predominance. A major difference from earlier criteria is that the presence of arthritis is no longer necessary for a diagnosis of sJIA. The diagnostic process is not simple, as infection and malignancy, as well as systemic autoimmune and other autoinflammatory diseases need to be excluded. During this process patients should be treated with NSAIDs, and once the diagnosis is confirmed the initial choice of treatment can, depending on the disease activity and joint affection, include NSAIDs, glucocorticoids, or IL-1 inhibitors. In refractory disease, other biologics (tocilizumab, abatacept, TNF-inhibitors) or methotrexate are introduced, depending on the joint affection.

\section{Autoinflammatory bone disease}

The hallmark of this group of disorders is sterile bone inflammation. Although the typical lesions histologically and radiographically mimic infective osteomyelitis, an infective agent cannot be isolated. Multifactorial autoinflammatory bone diseases are SAPHO syndrome and chronic recurring multifocal osteomyelitis (CRMO). Due to a number of common characteristics, some argue that these are in fact two forms of the same disease with a difference in the age of onset.

SAPHO is an acronym for the five major symptoms occurring in this syndrome: synovitis, acne, pustulosis, hyperostosis, and osteitis (33). It usually affects adolescents and younger adults, more often women. Bone and joint pain and edema are common presenting symptoms of the disease that in most cases affects the anterior thoracic wall (claviculae, sternum, sternoclavicular joints), followed by the spine, primarily its thoracic segment. The arthritis is of axial distribution in most cases. Skin changes occur before, during, or after the musculoskeletal symptoms, or they do not occur at all; they manifest as palmoplantar pustulosis, severe form of acne, suppurative hidradenitis, and pyoderma gangrenosum. CRMO is a spectrum of diseases that have in common sterile bone inflammation, as well as inflammatory skin and inflammatory bowel disease teasoma. To je proteinski kompleks koji sudjeluje pri uklanjanju otpadnih proteina u stanici i razlaganju stranih bjelančevina. Zbog njegove poremećene funkcije dolazi do nakupljanja otpadnih proteina u stanici i stimulacije proizvodnje interferona tipa I. Bolest započinje u prvim mjesecima života. Manifestira se najprije kožnim promjenama koje mogu biti nalik na ozebline, prstenastim plakovima ili eritematoznim edemima. Često se javljaju febriliteti. Nakon toga javljaju se lipodistrofija, odnosno gubitak masnog tkiva te, naposljet$\mathrm{ku}$, promjene na zglobovima. Liječenje se pokušava davanjem inhibitora JAK-a.

\section{Ubikvitinopatije}

Riječ je o poremećajima koji su usko vezani uz abnormalnosti signalnog puta NF- $\kappa B$ (15). Kao primjer može se navesti Blauov sindrom koji je uzrokovan autosomno dominantnom mutacijom u genu NOD2. Sindrom čini trijas rano nastaloga poliartikularnog artritisa (tenosinovitis), uveitisa (često panuveitis) i osipa (često male crvenkaste papule koje se ljuskaju), a promjene na koži i očima jesu nekazeozni granulomi. Bolesnici s otulipenijom imaju panikulitis, artritis i proljeve, a oni s haploinsuficijencijom A20 oralne ulceracije, uveitis i patergiju (stvaranje sterilnih pustula na mjestima traume). U bolesnika s manjkom proteina HOP i HOIL-1 nalazi se imunodeficijencija (učestale bakterijske i virusne infekcije).

\section{Multifaktorske inflamatorne bolesti}

Od multifaktorskih inflamatornih bolesti opisat ćemo sustavni oblik juvenilnog idiopatskog artritisa (sJIA) i autoinflamatorne bolesti kostiju koje se manifestiraju sterilnim upalnim osteolitičkim lezijama.

\section{Sustavni oblik juvenilnog idiopatskog artritisa (sJIA)}

Prema trenutačno vrijedećoj klasifikaciji Međunarodne lige za borbu protiv reumatizma iz 1997. (31), sJIA je najteži i najakutniji oblik JIA, koji nastaje interakcijom genskih i okolišnih čimbenika. sJIA se od ostalih oblika JIA, koji pripadaju skupini autoimunosnih bolesti, razlikuje po tomu što poremećaj prirođene imunosti ima važnu ulogu u patogenezi ove bolesti (tablica 5.). Prema najnovijim predloženim kriterijima Međunarodne organizacije za provođenje ispitivanja u dječjoj reumatologiji (PRINTO) iz 2019. godine, za postavljanje dijagnoze potrebno je da bolesnici imaju vrućicu nepoznata podrijetla, koja raste do $39^{\circ} \mathrm{C}$ ili više jedanput na dan i pada na $37^{\circ} \mathrm{C}$ ili niže, a prisutna je svakog dana najmanje 3 dana uzastopno i ponavlja se tijekom najmanje 2 tjedna (32). Uz to moraju biti zadovoljena dva glavna kriterija ili jedan glavni i jedan sporedni kriterij. Glavni kriteriji jesu eritematozni osip koji nije fiksan i iščezava te artritis. Sporedni kriteriji 
TABLE 6. Clinical signs suggestive of autoinflammatory disease TABLICA 6. Klinički znakovi koji upućuju na pojavu autoinflamatorne bolesti

\begin{tabular}{|l|}
\hline One or more of the following criteria: \\
/ Bolesnik koji ispunjava jedan ili više od ovih kriterija: \\
\hline - periodic/recurring fever \\
/ Periodične/rekurentne vrućice \\
\hline - severe skin inflammation (pustular dermatoses, painful \\
ulcerations, pustular psoriasis, granulomatous inflammation, \\
recurring urticarial changes...) \\
/ Teška upalna zahvaćenost kože (pustulozne dermatoze, \\
bolne ulceracije, pustulozna psorijaza, granulomatozne upale, \\
rekurentne urtikarijske promjene...) \\
\hline - severe bone and joint inflammation \\
/ Teška upalna zahvaćenost osteoartikularnog sustava \\
\hline - vasculopathies / Vaskulopatije \\
\hline - panniculitis/lipoatrophy / Panikulitis/lipoatrofija \\
\hline - serous membrane inflammation (peritonitis, pleuritis, \\
pericarditis) / Upale seroznih membrana (peritonitis, pleuritis, \\
perikarditis) \\
\hline - gastrointestinal tract inflammation / Upale probavne cijevi \\
\hline - amyloidosis / Amiloidoza \\
\hline - increased inflammatory markers during disease flares \\
(leukocytosis, increased C-reactive protein, increased \\
erythrocyte sedimentation rate, thrombocytosis) \\
/ Za vrijeme epizode bolesti povišeni upalni parametri \\
(leukocitoza, povišen C-reaktivni protein, ubrzana \\
sedimentacija eritrocita, trombocitoza) \\
\end{tabular}

(33). Most often they occur during childhood, between the ages of 7 and 12. Typically they present with bone pain with or without fever; the pain can be mild or acute, or intense with edema, warmth, and pathological fracture of the affected bones. The entire skeleton can be involved. Skin changes that occur are palmoplantar pustulosis, psoriasis, and pyoderma gangrenosum.

Whole-body MRI (investigation of choice) and radionuclide bone scan are used in establishing the diagnosis as well as in the follow-up. Sometimes a bone biopsy is needed to confirm the diagnosis. CRMO is managed with NSAIDs, antibiotics (clindamyicin, azithromycin, tetracyclines), glucocortikocids, and, in refractory cases, methotrexate, sulfasalatine, bisphosphonates, and TNF-inhibitors.

\section{An organ system-based summary \\ of the most common symptoms and signs of autoinflammatory diseases}

Since there are many autoinflammatory conditions that manifest with a broad spectrum of signs and symptoms that can overlap with those of various autoimmune diseases and immunodeficiencies, and since these are rare disorders, it is far more important to know when to suspect autoinflammatory disease than jesu generalizirana limfadenopatija i/ili hepatomegalija i/ili splenomegalija; serozitis; artralgija u trajanju od 2 tjedna ili dulje (u odsutnosti artritisa); leukocitoza $\left(15.000 / \mathrm{mm}^{3}\right.$ ili veća) uz neutrofiliju. Glavna je novost u odnosu prema dosadašnjim kriterijima da artritis više ne mora biti nužno prisutan da bi se postavila dijagnoza sJIA. Postavljanje dijagnoze nije jednostavno i temelji se na isključenju infekcija, malignih bolesti, sustavnih autoimunosnih bolesti i drugih autoinflamatornih bolesti. Do postavljanja dijagnoze primjenjuju se nesteroidni antireumatici (NSAID), a nakon postavljanja dijagnoze inicijalna terapija može, ovisno o stupnju aktivnosti bolesti i zahvaćenosti zglobova, uključivati primjenu NSAID-a, glukokortikoida ili inhibitora IL-1, dok se pri kontinuiranoj aktivnosti bolesti mogu uključiti i drugi biološki lijekovi (tocilizumab, abatacept odnosno inhibitori TNF- $\alpha$ ) ili metotreksat, ovisno o stupnju zahvaćenosti zglobova.

\section{Autoinflamatorne bolesti kostiju}

Osnovna karakteristika ovih bolesti jest sterilna upala kostiju, pri čemu lezije histološki i radiološki imitiraju infektivni osteomijelitis, ali se ne može izolirati infektivni uzročnik. U multifaktorske autoinflamatorne bolesti kostiju ubrajaju se sindrom SAPHO i kronični rekurentni multifokalni osteomijelitis (CRMO). Zbog mnogih zajedničkih značajka neki smatraju da se radi o dva oblika iste bolesti koje se pojavljuju u različitoj životnoj dobi.

SAPHO je akronim pet glavnih simptoma koji se javljaju u sklopu ovog sindroma: sinovitis, akne, pustuloza, hiperostoza i osteitis (33). Bolest se uglavnom pojavljuje $u$ adolescenata i mlađih odraslih, češće $u$ osoba ženskog spola. Prvi znak bolesti najčešće su bol i oteklina zglobova i kostiju. Najčešće je zahvaćen prednji dio prsnog koša: klavikula, sternum i sternoklavikularni zglobovi, a zatim kralježnica (najčešće torakalni segment). Artritis je najčešće aksijalni (zahvaća male zglobove kralježnice). Kožne promjene mogu se javiti prije, za vrijeme ili nakon koštano-zglobnih simptoma, a mogu i posve izostati. Uključuju palmoplantarnu pustulozu, teške oblike akna, supurativni hidradenitis i gangrenoznu piodermu. CRMO obuhvaća spektar bolesti kojima je zajednička sterilna upalna bolest kostiju uz upalne kožne i crijevne bolesti (33). Najčešće se javlja u djetinjstvu, i to u školskoj dobi (od 7 do 12 godina). Tipično se prezentira bolju u kostima $s$ febrilitetom ili bez njega, koja varira u intenzitetu od blage do akutne intenzivne boli, uz oteklinu, toplinu i patološku frakturu zahvaćenih kostiju. Lezije kostiju mogu zahvatiti cijeli skelet. Kožne promjene uključuju palmoplantarnu pustulozu, psorijazu i gangrenoznu piodermu.

Pri postavljanju dijagnoze ovih bolesti rabe se magnetska rezonancija cijelog tijela kao metoda izbora i za praćenje bolesnika, scintigrafija skeleta, a katkad je po- 
to know everything in detail about a single entity. Suspicion should be raised in patients with periodic and recurrent fever when infective, autoimmune, and malignant diseases have been excluded. Some autoinflammatory diseases have elements of immunodeficiencies causing recurrent infections. Also, it is good to know that some autoinflammatory diseases manifest without fever, thus the absence of fever is not an exclusion criterion.

The age of disease onset, ethnic origin, and family history are valuable medical data. Although the majority of these diseases begin in infancy, some can manifest for the first time in adulthood. Most of these conditions are not strictly geographically or ethnically linked; also, since many of them are caused by de novo or somatic mutations, in such cases the family history will be unremarkable. Almost all autoinflammatory diseases can be triggered by stress or infection; other triggering factors may be cold, minor trauma, pregnancy, menstruation, immunization, and exercise.

Skin inflammation should be considered as a "red flag" as almost all of these disorders affect the skin. Since the changes are not pathognomonic, a skin biopsy is necessary. Among the more common skin manifestations are non-pruritic urticaria-like changes, refractory to antihistamines, with neutrophilic infiltrates on histology. They can be found in CAPS and Schnitzler syndrome. Pustular dermatoses are found in Behçet disease and CRMO. Painful ulcerations and pyoderma gangrenosum are a part of PAPA syndrome and of very early inflammatory bowel disease. Granulomatous changes are found in Blau syndrome. Interferonopathies are characterized by vasculopathies, panniculitis, lipoatrophy, and frostbite-like changes, especially on the extremities. Plaques are common in FMF and TRAPS patients.

Musculoskeletal manifestations such as permanent or transient arthritis, synovitis, osteitis, and osteomyelitis, especially in cases of sterile pyogenic inflammation, should prompt suspicion of an autoinflammatory condition. Bone deformities and finger clubbing can be seen in severe forms of CAPS and in DIRA syndrome. Lytic and sclerotic bone lesions are a part of CRMO. Monoarthritis is common in FMF and PAPA syndrome, and polyarthritis in sJIA and mevalonate kinase deficiency. Intense myalgia is characteristic of FMF and TRAPS.

Eye manifestations include conjunctivitis, periorbital edema, and uveitis, which occur in most cases of CAPS and TRAPS. Behçet and NOMID cause the most severe eye pathology, which can result in blindness.

Gastrointestinal manifestations include abdominal pain, diarrhea, aphthae, and mucous ulcerations. Peritonitis is common in FMF and TRAPS. Diarrhea is common in mevalonate kinase deficiency, macrophage trebno učiniti i biopsiju kostiju. U liječenju se primjenjuju NSAID, antibiotici (klindamicin, azitromicin, tetraciklini), glukokortikoidi, a pri nezadovoljavajućem učinku mogu se primijeniti metotreksat, sulfasalazin, bisfosfonati i inhibitori TNF- $\alpha$.

\section{Sumarni prikaz najčešćih simptoma i znakova autoinflamatornih bolesti prema organskim sustavima}

Budući da je, $s$ jedne strane, autoinflamatornih bolesti mnogo i da se mogu manifestirati čitavim spektrom simptoma i znakova te preklapati $s$ autoimunosnim bolestima i imunodeficijencijama, a da su, s druge strane, te bolesti rijetke, mnogo je važnije od poznavanja pojedinih entiteta posumnjati na postojanje autoinflamatorne bolesti (tablica 6.). Još postoji znatna odgoda u postavljanju dijagnoze autoinflamatornih bolesti. $\mathrm{Na}$ njih treba posumnjati u bolesnika s periodičnim i rekurentnim vrućicama kod kojih je obrada na infekcije, autoimunosne i maligne bolesti negativna. U nekim autoinflamatornim bolestima bolesnici imaju znakove imunodeficijencije koji se manifestiraju ponavljanim infekcijama. Nadalje, treba napomenuti da postoje autoinflamatorne bolesti koje se ne manifestiraju febrilitetom, tako da odsutnost vrućice nije isključni kriterij za postojanje neke od ovih bolesti.

Važni anamnestički podatci uključuju dob pojave simptoma i znakova bolesti, etničko podrijetlo i obiteljsku anamnezu. Iako većina tih bolesti započinje u dječjoj dobi, one se mogu prvi put manifestirati tek u odrasloj dobi. Treba napomenuti da većina autoinflamatornih bolesti nije ograničena geografskom lokacijom ni podrijetlom bolesnika. Mnoge od njih uzrokovane su mutacijama de novo ili somatskim mutacijama pa će pritom obiteljska anamneza biti negativna. Gotovo sve autoinflamatorne bolesti mogu biti potaknute stresom i infekcijom, a od ostalih okidača treba spomenuti hladnoću, manje traume, trudnoću, mjesečni$\mathrm{cu}$, cijepljenje i vježbanje.

Sumnju treba pobuditi postojanje upalne zahvaćenosti kože. Naime, gotovo sve autoinflamatorne bolesti zahvaćaju i kožu. Budući da promjene nisu patognomonične, često je potrebno učiniti biopsiju kože. Jedna od čestih dermatoloških manifestacija jesu promjene nalik na urtikarijske, ali bez svrbeža, koje se ne povlače primjenom antihistaminika i kod kojih se biopsijom nalaze infiltrati neutrofila koji nisu karakteristični za urtikariju. One se mogu naći kod bolesnika s CAPS-om i Schnitzlerinim sindromom. Pustulozne dermatoze nalaze se kod bolesnika s Behçetovom bolesti i CRMO-om. Bolne ulceracije i pyoderma gangrenosum dio su kliničke slike sindroma PAPA, a mogu se naći i kod vrlo rane upalne bolesti crijeva. Granulomatozne promjene nalaze se u Blauovom sindromu. Pri interferonopatijama nalaze se vaskulopatije, paniku- 
activation syndrome, and very early-onset inflammatory bowel disease.

The spectrum of neurological disorders is broad vasculitis (Behçet disease), hearing loss (CAPS), psychomotor retardation (NOMID, interferonopathies). Convulsions are common in most of periodic fever syndromes.

Laboratory abnormalities such as leukocytosis, increased CRP, accelerated ESR, and thrombocytosis are common during disease episodes. However, some patients have only a mild increase in CRP, lymphopenia, and leukopenia during exacerbations. An unexplained increase of inflammatory markers, even when there are no other symptoms, should prompt suspicion of an autoinflammatory disease.

During the work-up of a patient with a suspected autoinflammatory disease it is necessary to exclude infection, malignancy, immunodeficiency, and rheumatic disease (34). A routine laboratory panel consisting of full blood count with differential and peripheral smear, ESR, CRP, electrolytes, urea, creatinine, LFTs, urinalysis, uric acid, and LDH should be ordered. Immunoserological tests (ANA, ANCA) should also be done. Initial microbiology testing consists of a throat swab, blood culture, urine culture, EBV serology, CMV serology, HIV test, and tuberculosis test. Chest X-ray is important in the initial work-up. Depending on the symptoms and differential diagnosis, additional tests can be performed: joint aspiration (to exclude septic arthritis), skin biopsy, audiometry (if CAPS is suspected), whole-body MRI (SAPHO, CRMO), heart ultrasound (FMF, TRAPS), lumbar puncture (CAPS), etc.

Over 30 different systemic autoinflammatory diseases are known today and over 800 genetic variants have been discovered; however, most of the latter are of unknown or undetermined impact or are not pathogenic (35). At the moment, genetic testing for autoinflammatory diseases is still burdened with various issues, and therefore in 50 to $60 \%$ of suspect cases a pathogenic mutation cannot be confirmed. The prinicipal indication for genetic testing is the presence of symptoms fulfilling the criteria for one or more autoinflammatory diseases. It is especially difficult to diagnose a patient with signs of overlap between various diseases, or in cases of a partial or atypical clinical course. In such patients, molecular analysis of an individual gene confirms the diagnosis in less than $20 \%$ of cases. Although there still are no official recommendations, genetic testing is sometimes a two-step procedure. In the first step, next generation sequencing methods are used for targeted testing through gene panels now available in various European centers. These tests will also be available in Croatia at the Department for Functional Genomics, a part of the University Hospital Center Zagreb Center for Translation- litis odnosno lipoatrofija te promjene nalik na ozebline, osobito na okrajinama. Plakovi se najčešće vide $u$ bolesnika s FMF-om i TRAPS-om.

Zahvaćenost koštano-zglobnog sustava manifestira se u obliku trajnog ili prolaznog artritisa, sinovitisa, osteitisa i osteomijelitisa, a napose nas sterilne piogene upale trebaju navesti na pomišljanje o autoinflamatornoj bolesti. Deformacije kostiju i batićasti prsti mogu se vidjeti u težim oblicima CAPS-a i pri sindromu DIRA. Litičke i sklerotične koštane lezije mogu se vidjeti u bolesnika s CRMO-om. Monoartritisi se najčešće vide kod FMF-a i sindroma PAPA, a poliartritis kod sJIA i nedostatka mevalonat kinaze. Naglašena mialgija karakteristična je za FMF i TRAPS.

Promjene na očima uključuju konjunktivitis, periorbitalni edem i uveitis, a najčešće se očne manifestacije nalaze u bolesnika s CAPS-om i TRAPS-om. Najteže promjene na očima, koje mogu rezultirati sljepoćom, vide se u bolesnika $\mathrm{s}$ Behçetovom bolesti i NOMID-om.

Gastrointestinalne manifestacije uključuju bol u trbuhu i proljev te pojavu afta i ulkusa na sluznicama probavnog sustava. Peritonitis je čest u FMF-u i TRAPS-u. Proljev se može naći kod bolesnika s manjkom mevalonat kinaze, u sindromu aktivacije makrofaga te pri upalnoj bolesti crijeva s vrlo ranim početkom.

Neurološki spektar poremećaja vrlo je širok. U nekim bolestima nalazimo vaskulitis (Behçetova bolest), u drugima gubitak sluha (CAPS), u nekima psihomotoričko zaostajanje (NOMID, interferonopatije). U mnogim sindromima periodičnih vrućica može doći do pojave konvulzija.

Za vrijeme epizode bolesti često se detektiraju povišeni upalni parametri: leukocitoza, povišen C-reaktivni protein (CRP), ubrzana sedimentacija eritrocita $i$ trombocitoza, premda neki bolesnici imaju umjereno povišen CRP, limfopeniju i leukopeniju u pogoršanjima bolesti. Na autoinflamatorne bolesti treba posumnjati i u bolesnika s neobjašnjenim povišenjem upalnih parametara, čak i ako nema simptoma bolesti.

Pri obradi bolesnika sa sumnjom na autoinflamatornu bolest potrebno je isključiti infekcije, zloćudne bolesti, imunodeficijencije i reumatske bolesti (34). Treba učiniti opće laboratorijske pretrage: krvnu sliku s diferencijalnom krvnom slikom i razmazom periferne krvi, brzinu sedimentacije eritrocita, CRP, elektrolite u serumu, ureju, kreatinin, hepatogram, analizu urina, određivanje mokraćne kiseline, laktat dehidrogenaze. Od imunoloških pretraga važni su nalazi antinuklearnih protutijela (ANA) i antineutrofilnih protutijela (ANCA). Od mikrobiološke obrade preporučuje se uzeti obrisak ždrijela, hemokulturu, urinokulturu, serologiju na Epstein-Barrin virus, citomegalovirus i virus humane imunodeficijencije te obaviti testiranje 
al and Clinical Research. If the first-step test results are negative, whole exome or whole genome sequencing is performed. The problem with these methods is the interpretation of the findings, especially in the case of de novo genetic variants, as it requires the application of complex software tools by personnel with extensive experience in bioinformatics and biostatistics.

Conflict of interest statement: Authors declare no conflict of interest.
Translated on English/Prijevod na engleski Krešimir RukAVINA na tuberkulozu. Od radioloških pretraga savjetuje se učiniti rendgenogram srca i pluća. Ovisno o simptomima i sumnji na pojedine bolesti, dodatno se mogu obaviti punkcija zgloba (radi isključenja infektivnog artritisa), biopsija kože, audiometrija (pri sumnji na CAPS), magnetska rezonancija cijelog tijela (SAPHO, CRMO), ehokardiografija (FMF, TRAPS), lumbalna punkcija (CAPS) i druge pretrage.

Do danas je poznato više od 30 različitih sustavnih autoinflamatornih bolesti te je otkriveno više od 800 genskih varijanta povezanih s autoinflamatornim bolestima od kojih je većina nepotvrđena, odnosno neodređena značenja ili nije patogena (35). Trenutačno je genska dijagnostika autoinflamatornih bolesti bremenita brojnim teškoćama te se u 50 do $60 \%$ bolesnika sa sumnjom na autoinflamatornu bolest ne uspije pronaći patogena mutacija. Glavna je indikacija za gensko testiranje prisutnost kliničkih simptoma koji ispunjavaju kriterije za jednu autoinflamatornu bolest ili više njih. Posebno je teško postaviti dijagnozu u bolesnika koji imaju obilježja koja se preklapaju između više bolesti ili imaju nepotpunu ili atipičnu kliničku sliku. Molekularna analiza pojedinačnoga gena u takvih bolesnika dovodi do dijagnoze u njih manje od 20\%. Iako još nema usuglašenih preporuka, katkad se gensko testiranje provodi u dva koraka. U prvome se metodama sekvenciranja sljedeće generacije provodi ciljano testiranje primjenom genskih panela koji su dostupni u različitim europskim laboratorijima, a uskoro će biti dostupni i u Hrvatskoj, na Odjelu za funkcionalnu genomiku u Centru za translacijska i klinička istraživanja Kliničkoga bolničkog centra Zagreb. Ako su rezultati takvog testiranja negativni, primjenjuje se sekvenciranje cijelog egzoma ili genoma. Problem s ovim metodama jest interpretacija nalaza, napose genskih varijanta de novo, što nalaže primjenu složenih softverskih alata i osoblja s velikim iskustvom u bioinformatici i biostatistici.

IZjAVA o sukobu interesa: Autori izjavljuju da nisu u sukobu interesa. 


\section{REFERENCES / LITERATURA}

1. Pathak S, McDermott MF, Savic S. Autoinflammatory diseases: update on classification diagnosis and management. J Clin Pathol. 2017;70:1-8.

2. McDermott MF, Aksentijevich I, Galon J i sur. Germline mutations in the extracellular domains of the $55 \mathrm{kDa}$ TNF receptor, TNFR1, define a family of dominantly inherited autoinflammatory syndromes. Cell. 1999;97:133-44.

3. Kastner DL, Aksentijevich I, Goldbach-Mansky R. Autoinflammatory disease reloaded, a clinical perspective. Cell. 2010; 140:784-90.

4. De Jesus AA, Goldbach-Mansky R. Genetically defined autoinflammatory diseases. Oral Dis. 2016;22:591-604.

5. Ben-Chetrit E, Gattorno M, Gul A i sur. Consensus proposal for taxonomy and definition of the autoinflammatory diseases (AIDs): a Delphi study. Ann Rheum Dis. 2018;77:1558-65.

6. McGonagle D, McDermott MF. A proposed classification of the immunological diseases. PLoS Med. 2006;3:e297.

7. Mujal AM, Krummel MF. Immunity as a continuum of archetypes. Science. 2019;364:28-9.

8. Hemminki K, Li X, Försti A, Sundquist J, Sundquist K. Incidence of hereditary amyloidosis and autoinflammatory diseases in Sweden: Endemic and imported diseases. BMC Med Genet. 2013;14:88.

9. Kenealy S, Creagh EM. Autoinflammatory Diseases: Consequences of Uncontrolled Inflammasome Activation. EMJ Allergy Immunol. 2018;3:106-13.

10. Georgin-Lavialle S, Fayand A, Rodrigues F, Bachmeyer C, Savey L, Grateau G. Autoinflammatory diseases: State of the art. Presse Med. 2019;48:e25-48.

11. Malenica B. Imunosni sustav i imunopatogeneza reumatskih bolesti. U: Jelušić M, Malčić I (ur.). Pedijatrijska reumatologija. 1. izd. Zagreb: Medicinska naklada; 2014.

12. Jelušić M, Morović Vergles J, Gagro A (ur.). Autoinflamatorne bolesti u djece i odraslih. Poslijediplomski tečaj stalnoga medicinskog usavršavanja. 1. izd. Zagreb: Medicinska naklada; 2017.

13. Crow YJ, Manel N. Aicardi-Goutières syndrome and the type I interferonopathies. Nat Rev Immunol. 2015;15:429-40.

14. Liu Y, Jesus AA, Marrero B i sur. Activated STING in a vascular and pulmonary syndrome. N Engl J Med. 2014;371:507-18.

15. Aksentijevich I, Zhou Q. NF- $\kappa B$ Pathway in Autoinflammatory Diseases: Dysregulation of Protein Modifications by Ubiquitin Defines a New Category of Autoinflammatory Diseases. Front Immunol. 2017;8:399.

16. Zhou Q, Yu X, Demirkaya E i sur. Biallelic hypomorphic mutations in a linear deubiquitinase define otulipenia, an early-onset autoinflammatory disease. Proc Natl Acad Sci USA. 2016; 113:10127-32.

17. Manthiram K, Zhou Q, Aksentijevich I, Kastner DL. The monogenic autoinflammatory diseases define new pathways in human innate immunity and inflammation. Nat Immunol. 2017;18:832-42.
18. John CC, Gilsdorf JR. Recurrent fever in children. Pediatr Infect Dis J. 2002;21:1071-7.

19. Gattorno M, Hofer M, Federici S i sur. Classification criteria for autoinflammatory recurrent fevers. Ann Rheum Dis. 2019;78: 1025-32.

20. Tran TA. Muckle-Wells syndrome: clinical perspectives. Open Access Rheumatol. 2017;9:123-9.

21. Booshehri LM, Hoffman HM. CAPS and NLRP3. J Clin Immunol. 2019;39:277-86.

22. Özen S, Batu ED, Demir S. Familial Mediterranean Fever: Recent Developments in Pathogenesis and New Recommendations for Management. Front Immunol. 2017;8:253.

23. Favier LA, Schulert GS. Mevalonate kinase deficiency: current perspectives. Appl Clin Genet. 2016;9:101-10.

24. Quintero J, Saba J, Garcia C. Tumor Necrosis Factor Receptor-1 Associated Periodic Syndrome: Case Report and Review of an Auto-inflammatory Disorder. Cureus. 2019;11:e3916.

25. Rigante D, Corina L. Periodic fever, aphthous stomatitis, pharyngitis and cervical adenitis (PFAPA) syndrome: A debate about diagnosis and treatment in children continues. Int J Pediatr Otorhinolaryngol. 2020;130:109830.

26. Cowen EW, Goldbach-Mansky R. DIRA, DITRA, and new insights into pathways of skin inflammation: what's in a name? Arch Dermatol. 2012;148:381-4.

27. Rao AP, Gopalakrishna DB, Bing X, Ferguson PJ. Phenotypic Variability in Majeed Syndrome. J Rheumatol. 2016;43:1258-9.

28. Holzinger D, Roth J. Alarming consequences - autoinflammatory disease spectrum due to mutations in proline-serine-threonine phosphatase-interacting protein 1. Curr Opin Rheumatol. 2016;28:550-9.

29. Eleftheriou D, Brogan PA. Genetic interferonopathies: An overview. Best Pract Res Clin Rheumatol. 2017;31:441-59.

30. Torrelo A. CANDLE Syndrome As a Paradigm of ProteasomeRelated Autoinflammation. Front Immunol. 2017;8:927.

31. Petty RE, Southwood TR, Manners P i sur. International League of Associations for Rheumatology. International League of Associations for Rheumatology classification of juvenile idiopathic arthritis: second revision, Edmonton, 2001. J Rheumatol. 2004;31:390-2.

32. Martini A, Ravelli A, Avcin T i sur. Toward New Classification Criteria for Juvenile Idiopathic Arthritis: First Steps, Pediatric Rheumatology International Trials Organization International Consensus. J Rheumatol. 2019;46:190-7.

33. Jelušić M, Čekada N, Frković M i sur. Chronic Recurrent Multifocal Osteomyelitis (CRMO) and Synovitis Acne Pustulosis Hyperostosis Osteitis (SAPHO) Syndrome - Two Presentations of the Same Disease? Acta Dermatovenerol Croat. 2018; 26:212-9.

34. Hashkes PJ, Laxer RM, Simon A (ur.). Textbook of Autoinflammation. 1. izd. Cham: Springer; 2019.

35. Rowczenio DM, Lachmann HJ. How to prescribe a genetic test for the diagnosis of autoinflammatory diseases? Presse Med. 2019;48:e49-59. 